\title{
Cellular and Molecular Pathways of Ischemic Neuronal Death
}

\author{
Seok Joon Won, Doo Yeon Kim ${ }^{\dagger}$ and Byoung Joo Gwag* \\ Center for the Interventional Therapy of Stroke and Alzheimers Disease, Department of Pharmacology, \\ Ajou University School of Medicine, San 5, Wonchondong, Paldalgu, Suwon, Kyungkido 442-749, South Korea \\ Genetics and Aging Research Unit, Massachusetts General Hospital East, \\ Building 114, Room 3012, 114 16th Street, Charlestown, MA 02129
}

Received 28 December 2001

\begin{abstract}
Three routes have been identified triggering neuronal death under physiological and pathological conditions. Excess activation of ionotropic glutamate receptors cause influx and accumulation of $\mathrm{Ca}^{2+}$ and $\mathrm{Na}^{+}$that result in rapid swelling and subsequent neuronal death within a few hours. The second route is caused by oxidative stress due to accumulation of reactive oxygen and nitrogen species. Apoptosis or programmed cell death that often occurs during developmental process has been coined as additional route to pathological neuronal death in the mature nervous system. Evidence is being accumulated that excitotoxicity, oxidative stress, and apoptosis propagate through distinctive and mutually exclusive signal transduction pathway and contribute to neuronal loss following hypoxic-ischemic brain injury. Thus, the therapeutic intervention of hypoxic-ischemic neuronal injury should be aimed to prevent excitotoxicity, oxidative stress, and apoptosis in a concerted way.
\end{abstract}

Keywords: Glutamate, Oxidative stress, Apoptosis, Ischemia, Necrosis

\section{Introduction}

Stroke occurs when local thrombosis, embolic particles, or the rupture of blood vessels interrupts the blood flow to the brain. While stroke is the third most common cause of death in most developed countries, it is ranked as the first leading cause of death and severe disability in Korea. Brain function is impaired immediately after the blood flow drops below one fourth of normal values. If the ischemic condition persists for a prolonged period of time, primary neuronal death appears rapidly in the core areas, and is accompanied by secondary

*To whom correspondence should be addressed.

Tel: 82-31-219-4221; Fax: 82-31-219-5069

E-mail: bjgwag@madang.ajou.ac.kr death in the ischemic penumbra that slowly evolves subsequent to the activation of multiple death pathways; therefore, it has been targeted for therapeutic intervention. The first line of interventional therapy stems from findings that excitotoxicity underlies one of the leading causes of neuronal death following hypoxic-ischemic insults. Accordingly, antagonists of ionotropic glutamate receptors have been developed. These reduce hypoxic-ischemic brain injury in various animal models, and have been applied for clinical trial of ischemic stroke, but with little therapeutic efficacy to date. Free radicals are primarily produced during a period of reperfusion, and are believed to contribute to delayed neuronal death. Finally, several lines of evidence suggest that apoptosis, or programmed cell death, comprises a portion of ischemic neuronal death. It is conceivable to postulate that the therapeutic intervention of ischemic neuronal death likely involves an appropriate combination of neuroprotective drugs that are designed to prevent excitotoxicity, oxidative stress, and apoptosis.

\section{Excitotoxicity}

Glutamate mediates excitatory synaptic transmission through the activation of ionotropic glutamate receptors that are sensitive to NMDA (N-methyl-D-aspartate), AMPA ( $\alpha$ amino-3-hydroxy-5-methyl-4-isoxazolepropionic acid), or kainate. This excitatory transmission mediates normal information processing and neuronal plasticity. An interrupted blood supply to the brain causes deprivation of oxygen and glucose that are utilized to produce energy. Impaired energy increases presynaptic glutamate release through membrane depolarization and the subsequent activation of the voltagegated $\mathrm{Ca}^{2+}$ channel. It also interferes with the re-uptake of glutamate (primarily into astrocytes), which results in the abnormal accumulation of synaptic glutamate. Excess and sustained activation of the ionotropic glutamate receptors causes fulminant neuronal death, namely glutamate neurotoxicity or excitotoxicity. 


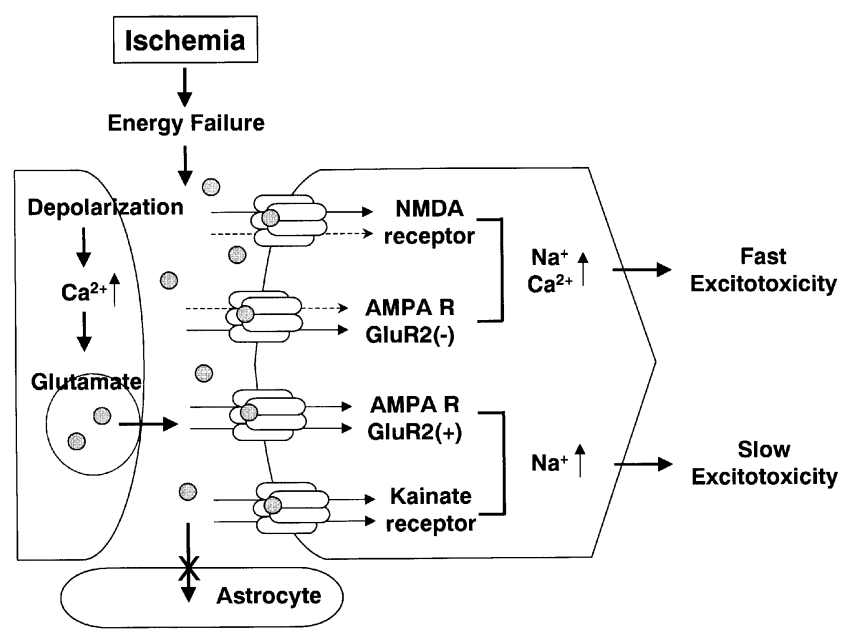

Fig. 1. Scheme of excitotoxic neuronal death in hypoxicischemic brain injury.

$\mathrm{Ca}^{2+}$-mediated fast excitotoxicity The pentameric NMDA receptors consist of the fundamental subunit NMDAR1 and modulatory subunits of NMDAR2A-2D (Hollmann and Heinemann, 1994; Sucher et al., 1996). The heteromeric NMDA receptors are highly permeable to $\mathrm{Ca}^{2+}$, as well as $\mathrm{Na}^{+}$ and $\mathrm{K}^{+}$. The NMDA receptors mediate slowly, evolving and desensitizing components of excitatory postsynaptic currents. NMDA receptors can be fully activated under the depolarization of plasma membrane that abolishes the inhibition of NMDA receptors by $\mathrm{Mg}^{2+}$. Since a brief (>3 min) activation of NMDA receptors is sufficient to trigger neuronal death, then the activation of NMDA receptors has been proposed as a primary cause of neuronal death after the focal cerebral ischemia that is accompanied by the transient $(\sim 30-$ $60 \mathrm{~min}$ ) elevation of extracellular glutamate (Benveniste et al., 1984; Takagi et al., 1993). The $\mathrm{Ca}^{2+}$ influx through NMDA receptors mediates the rapidly-triggered NMDA neurotoxicity, while $\mathrm{Na}^{+}$influx contributes to the swelling of the neuronal cell body (Choi, 1987) (Fig. 1).

AMPA receptors consist of a combination of GluR1-GluR4 subunits (Hollmann and Heinemann, 1994; PellegriniGiampietro et al., 1997). Most of the AMPA receptors are highly permeable to $\mathrm{Na}^{+}$and $\mathrm{K}^{+}$, and mediate rapidly, evolving and desensitizing components of excitatory postsynaptic currents. In contrast to NMDA, a prolonged (>60 min) activation of AMPA receptors is required to trigger neuronal death (Koh et al., 1990). While most neurons express the GluR2 subunit that renders AMPA receptors impermeable to $\mathrm{Ca}^{2+}$, the expression and function of GluR2 appear to be reduced in neurons that are vulnerable to hypoxic-ischemic insults. A transient forebrain ischemia produces delayed neuronal death in the CA1 hippocampal area that is preceded by the down-regulation of the GluR2 mRNA expression (Pellegrini-Giampietro et al., 1992; Gorter et al., 1997). NADPH diaphorase-containing neurons in the cortex and striatum express $\mathrm{Ca}^{2+}$-permeable AMPA receptors, and can undergo degeneration following a brief ( $\sim 10 \mathrm{~min})$ exposure to AMPA (Weiss et al., 1994). A single-cell RT-PCR analysis demonstrated that striatal diaphorase-containing neurons reveal a reduced ratio of GluR2/GluR1 and an unedited expression of GluR2 mRNA (Kim et al., 2001). This altered expression of GluR2 results in $\mathrm{Ca}^{2+}$-dependent AMPA neurotoxicity that may underlie potential mechanisms for selective neuronal death following hypoxic-ischemic brain injury.

The GluR5-7 and KA1-2 proteins comprise the subunits for functional KA receptors that are permeable to $\mathrm{Na}^{+}$and $\mathrm{K}^{+}$. The administration of kainate produces non-desensitizing currents at the AMPA receptors and fast desensitizing currents at the kainate receptors. Like the AMPA-mediated slow excitotoxicity, a prolonged $(>1 \mathrm{~h})$ exposure to kainate is needed to trigger neuronal death. It has been well-documented that the $\mathrm{Ca}^{2+}$ entry through the NMDA or AMPA receptors mediates the fast excitotoxicity; however, it still needs to be delineated to see how slowly excitotoxicity is triggered and propagated. One possibility is that the $\mathrm{Na}^{+}$entry through the AMPA or kainate receptors likely contributes to the AMPAor kainate- mediated slow excitotoxicity.

$\mathrm{Ca}^{2+}$ overload-induced neuronal death following hypoxicischemia The concentration of free $\mathrm{Ca}^{2+}$ in the cytoplasm of a resting neuron is extremely low (approximately $100 \mathrm{nM}$ ), whereas its extracellular concentration is estimated to 1-2 $\mathrm{mM}$. The intraneuronal levels of $\mathrm{Ca}^{2+}$ are maintained through the following: (1) The entry of extracellular $\mathrm{Ca}^{2+}$ through ligand-operated receptors or voltage-gated $\mathrm{Ca}^{2+}$ channels. (2) The release of $\mathrm{Ca}^{2+}$ from the endoplasmic reticulum through the stimulation of IP3 receptors, or from the mitochondria through the $\mathrm{Na}^{+}-\mathrm{Ca}^{2+}$ exchanger. (3) The extrusion of $\mathrm{Ca}^{2+}$ through the $\mathrm{Ca}^{2+}$-ATPase or $\mathrm{Na}^{+}-\mathrm{Ca}^{2+}$ exchanger in the plasma membrane. (4) The binding of $\mathrm{Ca}^{2+}$ to target proteins. (5) The sequestration of $\mathrm{Ca}^{2+}$ into the endoplasmic reticulum through $\mathrm{Ca}^{2+}$-ATPase, or mitochondria through electrophoretic (uniport) mechanisms (Gill et al., 1989; Gunter and Pfeiffer, 1990; Carafoli, 1991). Thus, energy failure in hypoxicischemia will cause the accumulation of intraneuronal free $\mathrm{Ca}^{2+}\left(\mathrm{Ca}^{2+}\right.$ overload $)$ by enhancing the entry and release of $\mathrm{Ca}^{2+}$, and interfering with the ATP-dependent extrusion and sequestration of $\mathrm{Ca}^{2+}$. The entry of $\mathrm{Ca}^{2+}$ through NMDA receptors appears to underlie a major portion of the $\mathrm{Ca}^{2+}$ overload following hypoxic-ischemia, as NMDA antagonists block the entry and accumulation of $\mathrm{Ca}^{2+}$ in central neurons that are deprived of oxygen and glucose (a hypoxic-ischemic condition in vitro) (Goldberg et al., 1987; Greenberg et al., 1990). Prolonged elevation of intracellular $\mathrm{Ca}^{2+}$ leads to the catabolic process of vital molecules and the irreversible death of neuronal cells through multiple mechanisms that involve the activation of $\mathrm{Ca}^{2+}$-dependent effector proteins.

(a) Calpains Calpains are a family of $\mathrm{Ca}^{2+}$-dependent cysteine proteases that consist of a $80 \mathrm{kD}$ catalytic subunit and a $30 \mathrm{kD}$ subunit (Sorimachi et al., 1997). Active calpain 
cleaves the vital proteins, such as spectrin, fodrin, $\mathrm{Ca}^{2+}$ ATPase, and protein kinase C, nuclear factor kappa B (Liu et al., 1996; Carafoli and Molinari, 1998). This contributes to the dendritic remodeling, interruption of membrane and cytoplasmic transportation, modulation of gene expression, and neuronal degeneration (Wang et al., 1990; Faddis et al., 1997; Wang, 2000). The activation of calpain I has been reported, following the activation of ionotropic glutamate receptors or hypoxic-ischemic insults (Seubert et al., 1988; Ostwald et al., 1993; Roberts-Lewis et al., 1994). Selective inhibitors of calpain I can reduce the NMDA-, kainate-, or AMPA-mediated excitotoxicity to some extent, and attenuate brain damage after hypoxia, focal cerebral ischemia, or transient global cerebral ischemia (Lee et al., 1991; Rami and Krieglstein, 1993; Hong et al., 1994). However, causative activation of calpain I for excitotoxicity has been challenged with findings that suggest that the blockade of calpain I by several inhibitors does not protect neurons from glutamate neurotoxicity (Manev et al., 1991; Faddis et al., 1997). In addition to calpains, other proteases, such as cathepsin D, are activated in cortical neurons that are exposed to NMDA or kainate (Yoon and Gwag, unpublished data). They are, therefore, likely to be involved in the process of excitotoxicity. (b) Cytosolic phospholipase A2 (cPLA2) Accumulated $\mathrm{Ca}^{2+}$ in neurons results in the translocation of cPLA2 into the plasma membrane. The $\mathrm{Ca}^{2+}$-activated cPLA2 produces free fatty acid (e.g. arachidonic acid) and lysophospholipids by catalyzing the cleavage of the free fatty acid from glycerophospholipids. Arachidonic acid is further utilized for the production of prostaglandins and leukotrienes with a concomitant production of superoxide (Kramer and Sharp, 1997; Sapirstein and Bonventre, 2000). The activation of cPLA2 may contribute to neuronal death in excitotoxicity and hypoxic-ischemia. The activity of cPLA2 is increased following focal cerebral ischemia, or in cultured neurons following the activation of ionotropic glutamate receptors (Dumuis et al., 1990; Lazarewicz et al., 1990; Sanfeliu et al., 1990; Kim et al., 1995; Saluja et al., 1997). Pharmacological inhibitors of cPLA2 reduce excitotoxic and hypoxic-ischemic neuronal death (Rothman et al., 1993; Bonventre, 1997). Moreover, knockout mice of cPLA2 (cPLA2-/-) substantially reduce cerebral infarct, brain edema, and neurological deficits following occlusion of the middle cerebral artery (Bonventre et al., 1997). Direct application of cPLA2 or melittin, a cPLA2 activator, produces neuronal death in cultured neurons and rats (Clapp et al., 1995). Thus, the $\mathrm{Ca}^{2+}$ overload through glutamate receptors induces the activation of cPLA2 that produces neurotoxic metabolites, such as prostaglandins, leukotrienes, reactive oxygen species, and platelet activating factors through the metabolism of arachidonic acid and lysophospholipids. While cPLA2 partly mediates the $\mathrm{Ca}^{2+}$ dependent excitotoxicity and hypoxic-ischemic injury, further study will be needed in order to delineate how the neurotoxic metabolites are coupled to the propagation and execution of neuronal death after hypoxic-ischemic injury. (c) $\mathrm{Ca}^{2+}$-dependent protein kinases The administration of glutamate results in the $\mathrm{Ca}^{2+}$-dependent inhibition, or the activation of the calcium/calmodulin protein kinase II (CaMK II) in the cortical and hippocampal neurons through the activation of NMDA glutamate receptors (Fukunaga et al., 1992; Morioka et al., 1995; Churn et al., 1995). The activity of CaMK II is decreased in a way that is sensitive to NMDA antagonists that rapidly follow transient focal or global cerebral ischemia (Hanson et al., 1994; Shackelford et al., 1995). While homozygous knock-out mice that lack the alpha subunit of CaMK II enhances sensitivity to hypoxic-ischemic insults in vivo (Waxham et al., 1996), a selective cellpermeable inhibitor of CaMK II (KN62) attenuates neuronal death, following exposure to NMDA, or the deprivation of oxygen-glucose in vitro (Hajimohammadreza et al., 1995). Therefore, the exact role of CaMK II needs to be studied in order to increase our understanding and assist in the therapeutic prevention of excitotoxic and hypoxic-ischemic neuronal death.

The administration of excitotoxins can activate major members of the mitogen-activated protein kinase (MAPK) family: p42/p44 extracellular signal-regulated kinases (ERK1 and 2), c-Jun N-terminal protein kinase (JNK)/stress-activated protein kinases (SAPKs), and p38 (Xia et al., 1996; Kawasaki et al., 1997; Ko et al., 1998; Vanhoutte et al., 1999; Schwarzschild et al., 1999). SAPK and p38 act as downstream mediators for the execution of neuronal and nonneuronal cell apoptosis (Cross et al., 2000). While activated p38 MAPK appears to mediate the NMDA-induced neuronal apoptosis in cerebellar granule cells (Kawasaki et al., 1997), inhibitors of p38 did not reduce the NMDA-induced neuronal cell necrosis in cortical cell cultures (Ko et al., 2000). In a recent report, PD98059 (a selective ERK inhibitor) was shown to reduce the infarct volume up to $55 \%$ by $1 \mathrm{~d}$, and $36 \%$ by 3 $\mathrm{d}$ following occlusion of the middle cerebral artery (Alessandrini et al., 1999). In addition to p38, ERKs and SAPKs probably participate in the process of excitotoxicity, as well as hypoxic-ischemic neuronal death.

(d) Endonucleases Intraneuronal $\mathrm{Ca}^{2+}$ overload or acidification can activate $\mathrm{Ca}^{2+} / \mathrm{Mg}^{2+}$-dependent endonucleases or DNAse II, respectively, that cleave to a region of the linker DNA between nucleosomes. This results in internucleosomal DNA fragments of multiples of 200 base pairs (or DNA ladders) (Robertson et al., 2000). The administration of glutamate, NMDA, AMPA, or kainate produces DNA ladders in cultured neurons and rat brains (Ankarcrona et al., 1995; Portera-Cailliau et al., 1995; Gwag et al., 1997). Although the activation of caspase- 3 mediates the liberation of caspaseactivated DNase (CAD)/DNA-dependent protein kinase-40 (DFF-40) by cleaving to the inhibitor of CAD (ICAD)/DFF45 then producing DNA ladders, the excitotoxins appear to produce DNA ladders through the activation of CADindependent endonucleases, since excitotoxins-induced DNA ladders are produced in the absence of caspase- 3 activation (Gwag et al., 1997; Ko et al., 2000). The process of DNA 
fragmentation has been implicated in chromatin condensation and morphological changes of nucleus in non-neuronal cells (Woo et al., 1998; Enari et al., 1998), but its role in excitotoxic neuronal death needs to be resolved.

(e) Nuclear factor kappa B The transcription factor, nuclear factor kappa B (NF- $\mathrm{KB})$, plays a dynamic role in the survival and death of neuronal and non-neuronal cells under physiological and pathological conditions (Baeuerle and Baltimore, 1996). Much research has established that the activation of NF- $\mathrm{KB}$ enhances neuronal survival by preventing apoptosis. The activation of NF- $\kappa \mathrm{B}$ by cytokines appears to be required for preventing the apoptosis of sensory neurons, which is documented by findings that the anti-apoptosis action of cytokines disappears in neurons that are treated with a super-repressor IkappaB-alpha protein, or lacking the RelA (p65) subunit of NF- $\kappa \mathrm{B}$ (Middleton et al., 2000). The inhibition of NF- $\kappa \mathrm{B}$ renders various types of cells highly vulnerable to apoptosis (Taglialatela et al., 1997). In contrast to the anti-apoptosis action of $\mathrm{NF}-\kappa \mathrm{B}$, controversial results have appeared regarding the causative role of $\mathrm{NF}-\kappa \mathrm{B}$ to excitotoxicity. Treatment with TNF or C2-ceramide reduced the excitotoxicity and free radical neurotoxicity through mechanisms that involved the activation of NF- $\kappa \mathrm{B}$ (Goodman and Mattson, 1996; Mattson et al., 1997). The administration of excitotoxins induces the activation of NF- $\kappa \mathrm{B}$ in neurons in vitro and in vivo (Grilli et al., 1996; Won et al., 1999). A causative activation of NF- $\mathrm{NB}$ has been proposed from findings that aspirin or salicylate prevents NMDA neurotoxicity by blocking the activation of NF- $\kappa \mathrm{B}$ (Grilli et al., 1996). However, this possibility has been challenged with the inhibitory action of aspirin or salicylate against the NMDA-induced activation of SAPK (Ko et al., 1998). Therefore, the exact role of NF- $\mathrm{KB}$ in excitotoxicity needs to be reexamined, turning to the pharmacological and genetargeted knockout of NF- $\mathrm{KB}$.

(f) Mitochondria Mitochondria constitute approximately $25 \%$ of the cytoplasmic volume, and produce cellular energy in the form of ATP via the electron transport and oxidative phosphorylation in most eukaryotic cells. Mitochondria are recognized as target organelles for the regulation and execution of cell death under pathological conditions (Budd and Nicholls, 1998; Kroemer et al., 1998). The role of mitochondria in excitotoxicity stems from various observations. First, the entry and accumulation of cytoplasmic $\mathrm{Ca}^{2+}$ through ionotropic glutamate receptors results in the subsequent accumulation of $\mathrm{Ca}^{2+}$ in mitochondria $\left(\left[\mathrm{Ca}^{2+}\right]_{\mathrm{m}}\right)$ (White and Reynolds, 1997; Peng et al., 1998). The cytoplasmic $\mathrm{Ca}^{2+}$ is transported into mitochondria through an electrophoretic uniporter. Its driving force is generated by the negative membrane potential, $\Delta \psi_{\mathrm{m}}$ (Gunter and Gunter, 1994). Second, mitochondria become depolarized, due to the transport of $\mathrm{Ca}^{2+}$ into the matrix and the inhibition of the oxidative phosphorylation (White and Reynolds, 1996; Ward et al., 2000; Rego et al., 2000). Third, inhibiting the mitochondrial $\mathrm{Ca}^{2+}$ uptake reduces the $\mathrm{Ca}^{2+}$-mediated glutamate neurotoxicity (Stout et al., 1998). Finally, increasing the mitochondrial membrane and redox potential blocks the accumulation in $\left[\mathrm{Ca}^{2+}\right]_{\mathrm{i}}$ and neuronal death following the activation of NMDA receptors (Seo et al., 1999). Excess $\mathrm{Ca}^{2+}$ in mitochondria results in mitochondrial dysfunction and neuronal death in various ways. With the accumulation of $\left[\mathrm{Ca}^{2+}\right]_{\mathrm{m}}$, ATP synthesis in mitochondria is impaired, due to the collapse of the mitochondrial oxidative phosphorylation (Wang et al., 1994; Khodorov et al., 1996). ATP depletion will interfere with the actions of ATPdependent $\mathrm{Ca}^{2+}$ pumps, amplify the accumulation of $\left[\mathrm{Ca}^{2+}\right]_{\text {i }}$, therefore enhancing the process of excitotoxic neuronal death. The activation of NMDA receptors produces reactive oxygen species in mitochondria, primarily through the inhibition of the oxidative phosphorylation and membrane potential (Rego et al., 2000; Seo et al., 1999). $\mathrm{Ca}^{2+}$-induced mitochondrial damage causes increased mitochondrial membrane permeability (Dubinsky and Levi, 1998), which can result in the mitochondrial release of cytotoxic substances, such as cytochrome c (Luetjens et al., 2000).

Oncosis versus apoptosis The activation of ionotropic glutamate receptors allows the entry of $\mathrm{Ca}^{2+}$ and $\mathrm{Na}^{+}$through the plasma membrane. The massive entry and accumulation of the cations induce the secondary influx of $\mathrm{Cl}^{-}$and $\mathrm{H}_{2} \mathrm{O}$, resulting in a marked swelling of the neuronal cell body within a few hours (Choi, 1987). Transmission electron microscopy reveals the swelling of cytoplasmic organelles, including mitochondria and the scattering condensation of nuclear chromatin early in the process of excitotoxicity (Gwag et al., 1997). Plasma membrane and cytoplasmic organelles are disrupted, but the nuclear membrane remains intact. In contrast to apoptosis (shrinkage necrosis), membrane blebbing is not observed in the process of excitotoxicity. The morphological features suggest that neurons undergo ${ }^{1}$ oncosis (swelling necrosis) following the superfluous activation of NMDA, AMPA, or kainate receptors. Although DNA ladders, TUNEL-positive neurons, and chromatin condensation are visible by DNA-binding, fluorescence dyes have been used as evidence of apoptosis in excitotoxicity (Ankarcrona et al., 1995; Portera-Cailliau et al., 1995); they are all observed in the process of necrotic cell death or oncosis (Gwag et al., 1995; Charriaut-Marlangue and Ben-Ari, 1995; Grasl-Kraupp et al., 1995; Sohn et al., 1998). Excitotoxic neuronal oncosis appears to propagate through signal transduction, which is different than oxidative stress and apoptosis, as neither antioxidants nor anti-apoptosis agents (e.g. inhibitors of macromolecule synthesis or growth factors) prevent excitotoxicity (Gwag et al., 1997 and 2000).

${ }^{1}$ Apoptosis means "shrinkage cell necrosis". As necrosis has been used often to describe "swelling cell necrosis", it seems to be more meaningful to use oncosis (derived from onkos, meaning swelling) instead of necrosis. 


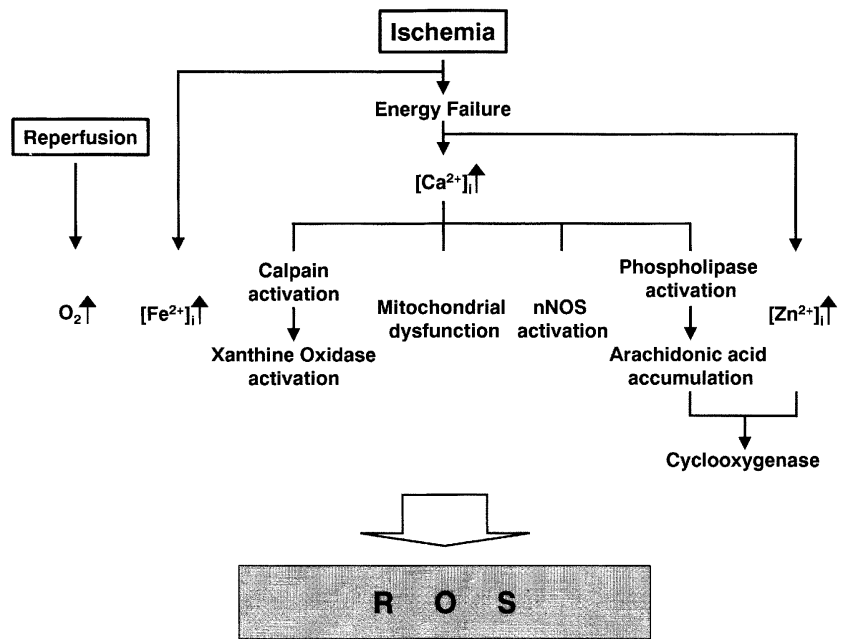

Fig. 2. Routes of ROS production following hypoxic-ischemic brain injury.

Limitation of anti-excitotoxicity therapy for hypoxicischemic injury The blockade of excitotoxicity can be applied to treat fulminant neuronal death that appears in hypoxic-ischemic patients. Therefore, a number of NMDA and AMPA/kainate receptor antagonists were developed for the prevention of hypoxic-ischemic neuronal death. Several NMDA receptor antagonists, including MK-801 and dextrophan, provide substantial protection against ischemic injuries that are induced by oxygen-glucose deprivation in vitro, or occlusion of the middle cerebral artery (Simon et al., 1984; Goldberg et al., 1987). Although NMDA receptor antagonists should be promptly delivered to ischemic patients for appropriate efficacy, most patients are hospitalized after 3 $\mathrm{h}$ after the onset of symptoms. The therapeutic potential of NMDA receptor antagonists is further limited by behavioral effects, such as psychosis and hyperlocomotion (Ouagazzal $e t$ al., 1993; Ellison, 1995), which are less protective effects against global ischemic injuries (Ross and Duhaime, 1989; Buchan et al., 1991), and direct neurotoxicity in several areas of the brain (Olney et al., 1991). While antagonists (such as NBQX) that act on AMPA and kainate receptors mitigate a selective neuronal loss following transient global ischemia in the rat (Sheardown et al., 1990), they are partially neuroprotective against focal ischemic insults (Buchan et al., 1991). The co-administration of NMDA and AMPA/kainate antagonists blocks excitotoxic neuronal oncosis, but reveals slowly-evolving apoptosis following hypoxic-ischemic insults (Gwag et al., 1995). Therefore, applying glutamate antagonists in order to treat hypoxic-ischemic injury should be compromised with the deleterious effects of the antagonist itself and appearance of glutamate-independent death pathways (e.g. apoptosis and oxidative stress). The former can be avoided with channel-blocking NMDA receptor antagonists with low affinity and a rapid-kinetic response (Rogawski et al., 2000).

\section{Oxidative stress}

Free radicals play an essential role in maintaining the physiological condition of the body. But, oxidative stress that is induced by an excess accumulation of the reactive oxygen species can damage basic components for cell function and survival. The brain accounts for about $20 \%$ of the aerobic metabolism. Neuronal cells are exposed to a minimum level of free radicals from both exogenous and endogenous sources in the normal condition. Since the brain has a minimum storage capacity for oxygen and a high probability of lipid peroxidation, then brain cells are especially vulnerable to free radical-mediated injury, such as oxygen interruption and reperfusion (Fig. 2).

Production of reactive oxygen species by $\mathbf{C a}^{2+}$ The loss of ATP during hypoxic-ischemia induces the dysfunction of active ion pumps, such as $\mathrm{Na}^{+}, \mathrm{K}^{+}$-ATPase (Welch et al., 1997). An abnormality of transmembrane ion gradient leads to neuronal plasma membrane depolarization, which opens the voltage-gated $\mathrm{Ca}^{2+}$ and $\mathrm{Na}^{+}$channels. The depolarization also stimulates the release of neurotransmitters, including glutamate into the synaptic cleft (Nicholls and Attwell, 1990). The accumulation of $\mathrm{Ca}^{2+}$ in neurons by the activation of $\mathrm{Ca}^{2+}-$ permeable glutamate receptors produces free radicals through the activation of prooxidant pathways, including phospholipases (Sevanian et al., 1983; Au et al., 1985), xanthine oxidase (McCord et al., 1985), and nitric oxide synthase (Dawson et al., 1992). The administration of glutamate to central neurons activates xanthine oxidase through the activation of NMDA receptors and $\mathrm{Ca}^{2+}$ dependent proteases (Atlante et al., 2000). Accumulated $\left[\mathrm{Ca}^{2+}\right]_{\mathrm{i}}$ induces the activation of the neutral protease calpain that results in the conversion of xanthine dehydrogenase into xanthine oxidase. Xanthine oxidase catalyzes the oxidation of xanthine and hypoxanthine into uric acid, producing superoxide as a by-product (McCord et al., 1985).

Production of reactive oxygen species in mitochondria Mitochondria produce ATP by utilizing about $90 \%$ of $\mathrm{O}_{2}$ that is taken up by neurons. During the electron transfer in the inner mitochondrial membrane, electrons spontaneously leak from the electron transport chain and react with available $\mathrm{O}_{2}$ to produce superoxide. The superoxide is normally cleared to $\mathrm{H}_{2} \mathrm{O}$ by superoxide dismutases and glutathione peroxidase. But, many free radicals that cannot be cleared by antioxidant enzymes are generated during ischemia, especially in reperfusion (Cao et al., 1988). An increase of oxygen during reperfusion induces the uncoupling of the electron flow from the mitochondria electron transport chain, causing the accumulation of free radicals. During hypoxic-ischemic injury, $\mathrm{Ca}^{2+}$ is accumulated in the cytosol (see above) and enters into mitochondria, which results in the production of mitochondrial free radicals (Hasegawa et al., 1993; Dykens, 
1994; Dugan et al, 1995; Giulivi et al., 1995; Piantodosi and Zhang, 1996). Excess $\mathrm{Ca}^{2+}$ in the mitochondria interrupts the electron transport chain and collapses the mitochondrial membrane potential (Zhang et al., 1990; Rego et al., 2000). Therefore, free electrons are accumulated in the mitochondria, which react with oxygen that is supplied after reperfusion, and causes the production of superoxide. The superoxide is further processed to produce the hydroxyl radical by a Fenton reaction or peroxynitrite by reacting with nitric oxide. The reactive oxygen and nitrogen species (ROS and RNS) also inhibit the electron transport chain in the mitochondria, and amplify a generation of mitochondrial free radicals (Zhang et al., 1990; Radi et al., 1994; Schweizer and Richter, 1994; Takehara et al., 1995; Cassina and Radi, 1996). Therefore, mitochondrial oxidative damage involves mitochondrial lipid peroxidation (Radi et al., 1993) and mitochondrial DNA oxidation (Giulivi et al., 1995).

Piantodosi and Zhang (1996) reported that the microdialysis of the hippocampus of rats that underwent transient global ischemia and reperfusion indicated a significant free radical formation during reperfusion. This ROS generation was also inhibited by infusion through the microdialysis probe of the complex I inhibitor, rotenone. Hasegawa (1993), and other studies using non-neuronal cells, provided evidence that mitochondria are free radical sources during ischemia. The reaction between superoxide and NO was reported to mediate toxicity that is associated with ischemia and reperfusion (Dawson et al., 1992; McCord et al., 1985).

Reactive nitrogen radicals Nitric oxide (NO or nitrogen monoxide) is an important messenger molecule in physiological conditions, and is synthesized by the activation of nitric oxide synthase (NOS). $\mathrm{Ca}^{2+} /$ calmodulin-dependent NOSs, such as neuronal NOS (nNOS) and endothelial NOS (eNOS), are activated by raised $\left[\mathrm{Ca}^{2+}\right]_{\mathrm{i}}$ (Knowles and Moncada, 1994). The expression of inducible NOS (iNOS) is increased in astrocytes and microglia by various cytokines, including interleukin-1, interleukin-2, interferon- $\gamma$, or the tumor necrosis factor (Murphy et al., 1993; Merrill et al., 1997). NO may exert neurotoxicity or neuroprotection, depending on the isoforms and localization of the activated NOS (Shim et al., 2001).

nNOS is expressed primarily in NADPH-diaphorasecontaining neurons, and activated by raised $\mathrm{Ca}^{2+}$ during hypoxic-ischemic injury (Lipton et al., 1993; Samdani et al., 1997). Inhibiting nNOS reduced the NMDA-mediated excitotoxicity, focal cerebral ischemia, global ischemia, and common carotid artery thrombosis (Dawson et al., 1993; Yoshida et al., 1994; ONeil et al., 1996; Kahn et al., 1997; Matsui et al., 1997; Stagliano et al., 1997; Nanri et al., 1998). NO that is derived from neurons can diffuse freely across membranes, and cause a degeneration of surrounding neurons. NO may react with superoxide to produce peroxynitrite $\left(\mathrm{ONOO}^{-}\right)$, another highly reactive free radical, that appears to mediate toxicity that is associated with ischemia and reperfusion (Radi et al., 1991a, b; Radi et al., 1994; Kooy et al., 1994). Peroxynitrite is ultimately converted to hydroxyl radical and nitrogen dioxide. These free radicals cause tissue damage by the nitration of DNA and proteins, as well as the oxidization of lipids, DNA, and proteins (Beckman, 1996; Yermilov et al., 1996). In addition, NO may produce neuronal death by activating poly (ADP-ribose) synthetase, thereby depleting beta-nicotinamide adenine dinucleotide (Zhang et al., 1994), and inhibiting mitochondrial ATP synthesis as an electron acceptor (Brookes et al., 1999).

NO can be produced in the endothelial cells of blood vessels through the activation of eNOS, released, and influence hypoxic-ischemic brain injury. Endothelial NO mediates vasodilation and prevents thrombosis. Therefore, endothelial NO appears to act as a neuroprotective signal against hypoxic-ischemia. This has been supported by recent findings that show that the inhibition of eNOS worsens neuronal death after hypoxic-ischemia (Dalkara et al., 1994; Shapira et al., 1994; Stagliano et al., 1997). Finally, the expression of iNOS increased in glial cells and neutrophils several days after reperfusion, which provided a substantial amount of NO in the ischemic area (Iadecola et al., 1995a). The induction of iNOS potentiates neuronal death following the deprivation of oxygen and glucose, while the inhibition of iNOS reduces the infarct volume after transient cerebral ischemia (Iadecola et al., 1995b). Increased levels and activation of iNOS appear to contribute to a somewhat delayed neurotoxicity following hypoxic-ischemic injury.

Production of reactive oxygen species by transition metals Transition metals are one of the most important factors that produce the reactive oxygen species, and they are implicated in the generation of ROS in various neurodegenerative diseases (Youdim et al., 1993; Deibel et al., 1996). These transition metals mediate the formation of the hydroxyl radical through the iron-catalyzed or copper-catalyzed HaberWeiss reactions (Haber and Weiss, 1934). $\mathrm{Fe}^{2+}$ is released from surrounding cells and iron-binding proteins during transient focal ischemia. The released $\mathrm{Fe}^{2+}$ can also convert hydrogen peroxide to hydroxyl radical, and may mediate lipid peroxidation during reperfusion (White et al., 1985; Zaleska and Floyd, 1985). Late-onset iron deposition was also observed after transient focal ischemia in rat brain (Kondo et al., 1995). The transition metal $\mathrm{Zn}^{2+}$ mediates the death of neuronal and non-neuronal cells in hypoxic-ischemia, epilepsy, and trauma (Koh et al., 1996; Cole et al., 2000; Lee et al., 2000; Suh et al., 2000). $\mathrm{Zn}^{2+}$ is stored in the presynaptic vesicles of glutamatergic neurons, released with glutamate in an activity dependent manner, and translocated into adjacent neurons (Frederickson and Moncrieff, 1994). The $\mathrm{Zn}^{2+}$ translocation was observed in degenerating neurons after transient forebrain ischemia (Koh et al., 1996; Suh et al., 2000). This ischemic neuronal death was prevented by the blockade of $\mathrm{Zn}^{2+}$ translocation with Ca-EDTA, or the 
overexpression of metallothionein-1, a $\mathrm{Zn}^{2+}$-binding protein (van Lookeren et al., 1999). $\mathrm{Zn}^{2+}$ ions enter into target cells through voltage-gated calcium channels (VGCC), NMDA, or AMPA/kainate glutamate receptors that are permeable to $\mathrm{Ca}^{2+}$, $\mathrm{Na}^{+} / \mathrm{Ca}^{2+}$ exchanger, or $\mathrm{Zn}^{2+}$ transporter (Freund and Reddig, 1994; Koh and Choi, 1994; Sensi et al., 1997; Sensi et al., 1999; Colvin et al., 2000). The entry and accumulation of $\mathrm{Zn}^{2+}$ into neurons result in the transient generation of reactive oxygen species that mediate latent neuronal death (Sensi et al., 1999; Kim et al., 1999; Kim et al., 1999). $\mathrm{Zn}^{2+}$ produces ROS, possibly through the activation of cyclooxygenases and PKC (Kim et al., 1999; Noh and Koh, 2000). Also, $\mathrm{Zn}^{2+}$ induced neuronal cell death by energy failure and the addition of pyruvate attenuated cell death, recovered the level of ATP and NAD (+) (Sheline et al., 2000). In addition, pyruvate prevented neuronal death following transient forebrain global ischemia (Lee et al., 2001).

Metabolism of arachidonic acid Glutamate or hypoxicischemia produces arachidonic acid through the activation of $\mathrm{PLA}_{2}$ (see above). Arachidonic acid is converted into eicosanoids with a concomitant production of superoxide by cyclooxygenases and 5-lipooxygenase (Kontos, 1987; Krause et al., 1988). An increased expression and activation of COX2 was observed in neurons and glial cells in rodent and human ischemic brains (Planas et al., 1995; Collaco-Moraes et al., 1996; Sairanen et al., 1998). They were shown to depend upon activation of NMDA receptors in neurons (Miettinen $e t$ al., 1997). COX-2 inhibition attenuates NMDA-mediated excitotoxicity and hypoxic-ischemic injury (Hewett et al., 2000; Iadecola et al., 2001). Recently, the activation of constitutive COX-2 was shown to mediate $\mathrm{Zn}^{2+}$-induced free radical production and neurotoxicity in cortical cell cultures (Kim et al., 1999). The exact role of activated COX-2 in neurons and non-neuronal cells needs to be determined in order to correlate the free radical production and neuronal death following hypoxic-ischemia. However, hypoxicischemic injury worsened with the reduction of cerebral blood flow at the periphery of the ischemic territories in COX-1 deficient mice (Iadecola et al., 2001). The inhibition of lipoxygenase, the other catalytic enzyme of arachidonic acid, attenuates neuronal injury that is induced by oxygen-glucose deprivation in a hippocampal slice (Arai et al., 2001).

Apoptosis versus oncosis Accumulated ROS in cells are expected to randomly attack DNA, lipid, and proteins; therefore, they produce cell death in a way that is different than apoptosis, which is propagated through a cascade of well-orchestrated molecular events. However, a lot of evidence suggests that ROS may act as mediators of apoptosis in non-neuronal cells. First, ROS are produced in the process of apoptotic cell death (Hockenbery et al., 1993; Bredesen, 1994; Prehn et al., 1997; Krohn et al., 1998). Second, ROS scavengers prevent apoptosis (Hockenbery et al., 1993; Troy and Shelanski, 1994; Greenlund et al., 1995; Kruman et al.,
1998). Third, exposure to pro-oxidants can induce apoptosis (Ratan et al., 1994; Whittemore et al., 1995). The causative role of ROS for apoptosis has been reported in various populations of neurons (Ratan et al., 1994; Whittemore et al., 1995). These turn mainly to DNA ladders, DNA-binding fluorescence dyes, and the TUNEL method that do not differentiate apoptosis from oncosis (see above). We also observed that cortical cell cultures are exposed to prooxidants, such as $\mathrm{Fe}^{2+}$ or buthionine sulfoximine revealed DNA ladders, condensation of nuclear chromatin, and TUNEL-positive neurons (Ryu et al., 1998). However, an ultrastructural analysis of free radical neurotoxicity demonstrated the occurrence of typical oncosis in most neurons, which is evident by the swelling of the cell body and mitochondria, scattering condensation of nuclear chromatin, and fenestration of the plasma membrane prior to nuclear membrane (Ryu et al., 1998).

Limitation of anti-oxidant therapy for hypoxic-ischemic injury As documented, free radicals (e.g. ROS and RNS) contribute to hypoxic-ischemic neuronal death. The pharmacological or genetic intervention of ROS and RNS has been neuroprotective against hypoxic-ischemic injury, as discussed previously. However, neither tirilazad mesylate (a lipid peroxidation inhibitor), nor ebselen (a seleno-organic compound with antioxidant activity) failed to show therapeutic efficacy in the primary outcome measure of stroke patients. This lack of efficacy may be attributed to the inappropriate administration of drugs, which were insufficient to block the ROS production following hypoxic-ischemia. In addition, the blockade of ROS neurotoxicity may result in the appearance of the other death pathways, excitotoxicity, and apoptosis.

\section{Apoptosis}

Kerr et al. (1972) reported electron microscopic features of shrinkage necrosis or apoptosis that could play a role in the regulation of cell numbers under physiological and pathological conditions. The condensation of nucleus and cytoplasm, nuclear fragmentation, and the aggregated

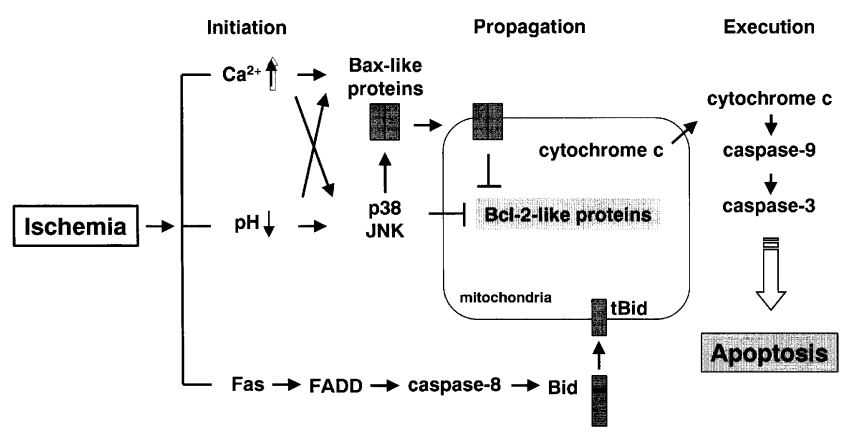

Fig. 3. Multiple pathways for hypoxic-ischemic neuronal apoptosis. 
condensation of nuclear chromatin accompanied apoptotic cells. Interestingly, apoptosis is prevented by the inhibitors of protein and mRNA synthesis; therefore, they appear to require the expression and activation of death-regulating proteins in neurons and non-neuronal cells (Wyllie et al., 1984; Martin et al., 1988). The morphological and molecular features of apoptosis have been reported in the nervous system during development and various neurological diseases. Apoptosis has been recognized as an additional pattern of hypoxic-ischemic neuronal death. Various pro-apoptosis proteins are activated in ischemic brain areas, and inhibitors of protein synthesis attenuate hypoxic-ischemic neuronal death (Fig. 3). The inhibitors of caspases, or the overexpression of $\mathrm{Bcl}-2$, attenuate neuronal death following focal and global ischemia. Although evidence has accumulated that demonstrates the occurrence of neuronal apoptosis after hypoxic-ischemic insults, there remains the need to determine how the interruption of the blood supply to the brain triggers neuronal cell apoptosis.

Acidosis The decrease of blood flow $(<50 \%)$ by hypoxicischemic injury induces the depletion of ATP and the accumulation of lactate within a few minutes (Welch et al., 1997). The intracellular acidification by excess $\mathrm{CO}_{2}$, and the dysfunction of active ion pumps by the loss of ATP, is considered a primary cause of cell death (Siesjo et al., 1996). The possibility has been raised that the intracellular acidification comprises an event in the process of apoptosis, such as an increase of ICE-like protease activity (Furlong et al., 1997; Matsuyama et al., 2000). The collapse of the proton gradient across the mitochondrial inner membrane by a decrease of ATP can result in a complete loss of the mitochondrial membrane potential. The cytochrome $\mathrm{c}$ in the cytosol that is released by the permeability of the outer mitochondrial membrane binds to Apaf-1, activates procaspase-9, and leads to the activation of downstream caspases, such as caspase-3 (Earnshaw et al., 1999). Hypoxicischemia, or the apoptosis-inducing protein kinase inhibitor staurosporine, causes acidification in the cytosol that promotes the activation of cytochrome c-dependent caspases and acidic endonucleases (Matsuyama et al., 2000). The intracellular acidification caused apoptosis in cultured neurons and haematopoietic cells (Furlong et al., 1997; Ding et al., 2000). Growth factors, and the anti-apoptosis members of Bcl-2, prevented cytosolic acidification, which probably resulted in the attenuation of caspase activation and apoptosis (Reynolds et al., 1996; Furlong et al., 1997; Khaled et al., 1999). It is possible that acidosis may mediate neuronal apoptosis following hypoxic-ischemic insults.

Calcium imbalance Hypoxic-ischemic insults to the brain can cause an excess accumulation of $\mathrm{Ca}^{2+}$ in neurons (see above). While the disrupted ion homeostasis produces neuronal cell oncosis (as shown in excitotoxicity), the selective accumulation of intracellular $\mathrm{Ca}^{2+}$ can cause neuronal apoptosis. Raised $\left[\mathrm{Ca}^{2+}\right]_{i}$ by $\mathrm{Ca}^{2+}$ ionophores causes neurite damage, depriving cell bodies of target-derived neurotrophic factors. It then produces hallmarks of apoptosis, such as DNA ladders, shriveled cell body, aggregated and condensed nuclear chromatin, and sensitivity to various anti-apoptosis agents (Gwag et al., 1999). When neurons are exposed to NMDA in low levels of extracellular $\mathrm{Na}^{+}$, they become more permeable to $\mathrm{Ca}^{2+}$, and reveal apoptotic features (Yu et al., 1999). Raised $\left[\mathrm{Ca}^{2+}\right]_{\mathrm{i}}$ can trigger apoptosis through mechanisms that involve the activation of calpain, caspases, $\mathrm{PLA}_{2}$, and endonucleases, which is observed following the focal and global cerebral ischemia (Rordorf et al., 1991; Neumar et al., 1996; Rosenbaum et al., 1998; Namura et al., 1998).

Fas receptor The death receptor Fas (CD95 or APO-1) belongs to the tumor necrosis factor (TNF) receptor superfamily, and plays a role in death and survival, as well as proliferation and differentiation (Nagata, 1997; Strasser et al., 2000). Fas ligand (Fas-L) activates Fas in an autocrine or paracrine fashion, which causes the trimerization of Fas with Fas-associating proteins with death domain (FADD) and procaspase-8. The activation of Fas has been demonstrated as a necessary step for apoptosis of neuronal cells that are deprived of trophic factors (Cheema et al., 1999; LeNiculescu et al., 1999; Raoul et al., 1999). The expression of Fas and Fas-L is increased in the ischemic brain area following hypoxic-ischemic injury (Matsuyama et al., 1995; Herdegen et al., 1998; Martin-Villalba et al., 1999; Felderhoff-Mueser et al., 2000; Matsushita et al., 2000). The recruitment of FADD, and procaspase- 8 or 10 , to Fas is observed in the cerebral cortex and hippocampal formation that is subjected to focal cerebral ischemia and global forebrain ischemia, respectively (Won et al., 2000; Jin et al., 2001). This implies that the Fas-mediated death pathway may underlie hypoxic-ischemic neuronal apoptosis. In support of this, the infarct size following occlusion of the middle cerebral artery is reduced in lpr mice that are deficient in Fas (MartinVillalba et al., 1999). Further study will be needed to understand the mechanisms for the expression of Fas and Fas$\mathrm{L}$, and to correlate the Fas pathway and neuronal apoptosis following hypoxic-ischemic injury.

MAP kinases MAPKs, p42/p44 extracellular signalregulated kinases (ERK 1 and 2), c-Jun $\mathrm{N}$-terminal kinases (JNK), and p38 mitogen-activated protein kinase, play a role in the development and survival of neurons and non-neuronal cells (Ip and Davis, 1998). Among these, JNK and p38 have been established as the common mediators of cell death (Mielke and Herdegen, 2000). In the brain, JNK and p38 are activated to execute apoptotic death of neuronal cells following trophic factor deprivation, or exposure to calyculin A, Haloperidol or NO donors (Xia et al., 1995; Kummer et al., 1997; Ko et al., 1998; Maroney et al., 1998; Noh et al., 2000; Ghatan et al., 2000). The activation of JNK and p38 is 
also observed in the vulnerable brain areas after hypoxicischemic injury (Herdegen et al., 1998; Ozawa et al., 1999; Irving et al., 2000). The administration of SB203580, a p38 inhibitor, reduces the infarct size after the transient focal cerebral ischemia, and the delayed neuronal death in the CA1 sector after global forebrain ischemia (Sugino et al., 2000; Barone et al., 2001). This suggests that p38, and possibly JNK, may mediate the execution of hypoxic-ischemic neuronal apoptosis. Activated JNK and p38 may execute apoptosis by preventing the anti-apoptosis actions of Bcl-2 and $\mathrm{Bcl}-\mathrm{X}_{\mathrm{L}}$. This activates the translocation of the cytosolic Bax into mitochondria, which then activates the mitochondrial apoptosis signals, such as the cytochrome c release (Srivastava et al., 1999; Kharbanda et al., 2000; Ghatan et al., 2000; Tournier et al., 2000). In recent U0126, a specific inhibitor of MEK (MAPK/ERK kinase), protected the hippocampal neuronal death after the forebrain ischemia concurrent with a reduction of ERK2 phosphorylation (Namura et al., 2001).

The pro-apoptotic family of Bcl-2 The physiological and pathological roles of the Bcl-2 family of proteins have been extensively reviewed (Merry and Korsmeyer, 1997; Chao and Korsmeyer, 1998). In general, the physical balance between anti-apoptotic and pro-apoptotic members of the Bcl-2 family appears to determine the death and survival of developing and mature cells. The pro-apoptotic Bcl-2 family includes Bax, $\mathrm{Bcl}-\mathrm{x}_{\mathrm{s}}, \mathrm{Bak}, \mathrm{Bad}$, and Bid. They participate in the process of hypoxic-ischemic neuronal death. The expression of Bax is increased selectively in neurons undergoing apoptosis after global forebrain ischemia and focal cerebral ischemia (Krajewski et al., 1995; Isenmann et al., 1998). The cerebral infarct, and the delayed neuronal death in the hippocampus, are significantly reduced in mice and gerbil that over-express Bcl-2, respectively (Martinou et al., 1994; Snider et al., 1999; Antonawich et al., 1999). Hypoxic-ischemia can activate the pro-apoptotic Bcl-2 family, possibly through two separate routes. The intracellular acidosis can induce a $\mathrm{pH}$-sensitive conformational change of Bax, then the translocation of Bax into mitochondria (Khaled et al., 1999). Bax is oligomerized, inserted into the outer membrane of mitochondria, and in turn shown to induce the cytochrome $\mathrm{c}$ release, caspase activation, and apoptosis (Hsu et al., 1997; Gross et al., 1998). Alternatively, raised $\left[\mathrm{Ca}^{2+}\right]_{\mathrm{i}}$ induces the BAD dephosphorylation and dissociation from 14-3-3 in the cytosol through the activation of the protein phosphatase calcineurin, which results in the BAD translocation to mitochondria and heterodimerization with Bcl-xL (Wang et al., 1999; Khaled and Durum, 2001)). Bid, another pro-apoptotic Bcl-2 family, also mediates the caspase- 8 dependent-neuronal death after oxygen-glucose deprivation, and focal cerebral ischemia. Also, Bid-/- mice are resistant to ischemic injuries against focal cerebral ischemia (Plesnila et al., 2001).

Caspases The caspases, a family of cysteine-dependent aspartate-directed proteases, mediate the propagation and execution of apoptosis. They can be classified into "initiator caspases" and "effector caspases" (Earnshaw et al, 1999). The initiator caspase, caspase-9, is proteolytically activated by apaf-1, a cytoplasmic protein that is homologous to ced-4, and cytochrome c. The mitochondria Bax-like proteins may rupture the outer mitochondrial membrane, or induce the formation of a channel complex for the cytochrome c release (Desagher and Martinou, 2000). Another initiator caspase caspase- 8 is activated through the interaction of procaspase- 9 with the Fas receptor and FADD adapter. The activation of caspase-8, caspase-9, or caspase-10 is observed in the vulnerable brain areas prior to the appearance of neuronal apoptosis following global and focal hypoxic-ischemic injury in the brain (Krajewski et al., 1999; Velier et al., 1999; Won et al., 2000; Jin et al., 2001). Activated caspase-8 and caspase-9 can induce activation of downstream caspases, such as caspase-3, 6, and 7, that can cleave a number of proteins that are essential for the structure, signal transduction, and cell cycle. This results in the termination of the overall apoptosis process. Caspase-3-mediated neuronal death has been reported following hypoxic-ischemia in vitro and in vivo (Gottron et al., 1997; Chen et al., 1998; Namura et al., 1998; Fujimura et al., 1998; Sugawara et al., 1999).

Reevaluation of ischemic neuronal apoptosis Wyllie (1980) reported that genomic DNA cleaved into the oligonucleosomal size in the course of apoptosis. This internucleosomal DNA fragmentation (or DNA ladders) has been shown using the agarose gel electrophoresis of DNA and the terminal deoxynucleotidyl transferase mediated dUTPbiotin nick end labeling (TUNEL) method. It is widely accepted as a way to define apoptosis (Wyllie, 1980; Gavrieli et al., 1992). In addition, the apoptotic condensation of the nuclear chromatin has been demonstrated using membranepermeable fluorochromes (e.g. Hoechst dye and propidium iodide) that bind to DNA (Nicoletti et al., 1991; Darzynkiewicz et al., 1992). As DNA ladders, TUNELpositive neurons and chromatin condensation were observed in the process of neuronal death in the hypoxic-ischemic brain areas; apoptosis, as well as oncosis, have been considered as additional types of hypoxic-ischemic neuronal death (Linnik et al., 1993; MacManus et al., 1993; Li et al., 1995). However, similar patterns of DNA damage are observed in the process of the necrotic cell, suggesting that the analysis of DNA damage is insufficient to define apoptosis (Enlight et al., 1994; Grasl-Kraupp et al., 1995; Sohn et al., 1998). The electron microscopic examination revealed that neurons primarily undergo oncosis that is evident by the swelling of the cell body and mitochondria, translucent cytoplasm, scattering condensation of the nuclear chromatin, and fenestration of the plasma membrane with the preserved nuclear membrane following occlusion of the middle cerebral artery (Fig. 4). Similar morphological patterns of degenerating neurons were reported in the hippocampal region following global forebrain ischemia (Li et al., 1995; Colbourne et al., 1999). Therefore, 


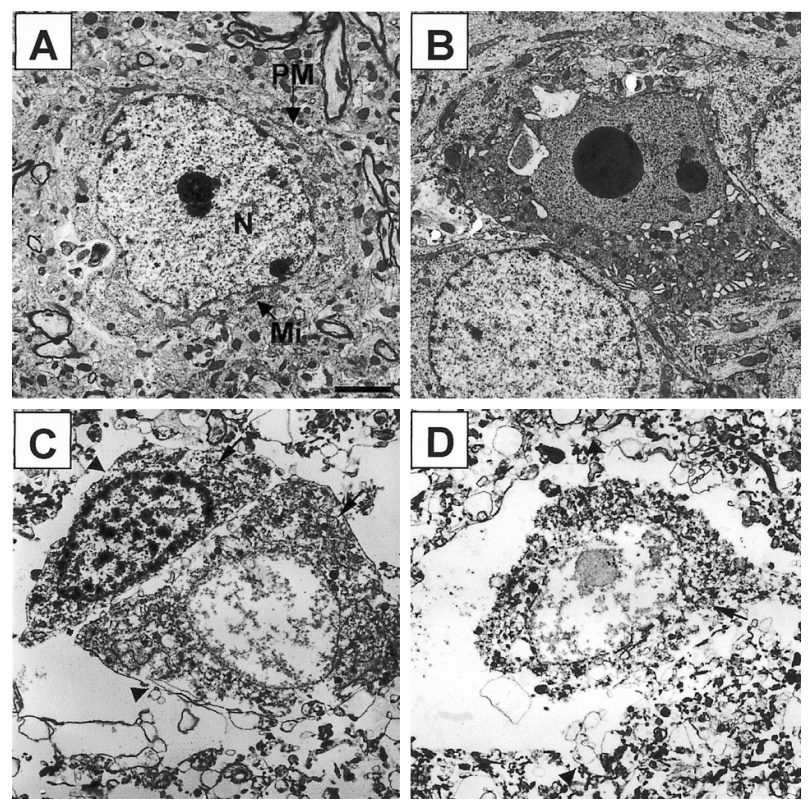

Fig. 4. Transmission electron micrographs of a normal neuron (A). A typical apoptotic neuron in the dentate gyrus $1 \mathrm{~d}$ after the intraventricular injection of colchicines (B). Neurons showing necrotic features 1 day after occlusion of the middle cerebral artery for $60 \mathrm{~min}$ (C and D). Abbreviations: N, nucleus; PM, plasma membrane; Mi, mitochondria. Scale bar, $2.5 \mu \mathrm{m}$.

hypoxic-ischemic insults to the brain appear to produce neuronal cell oncosis, possibly through mechanisms that involve excitotoxicity and oxidative stress (Table 1). While some biochemical and molecular events underlying apoptosis have been observed following focal cerebral ischemia and global forebrain ischemia, the fulminant necrotic pathway may override these. The apoptosis component of hypoxicischemic neuronal death may be revealed with the blockade of excitotoxicity and oxidative stress (Gwag et al., 1995).

\section{Maximization for Prevention of Hypoxic-ischemic Neuronal Death}

While antagonizing excitotoxicity does reduce neuronal death after hypoxic-ischemic injury, its beneficial effect is questioned by some unwanted observations. Systemic injections of NMDA antagonists alone produce neuronal vacuolization and death in adult rats (Fix et al., 1993). Neuronal death by NMDA antagonists reveals a hallmark of apoptosis, such as shrinkage of the cell body, aggregated condensation of nuclear chromatin, and sensitivity to the inhibitors of protein synthesis (Fix et al., 1993; Ikonomidou et al., 1999; Hwang et al., 1999; Takadera et al., 1999). In addition, a prolonged deprivation of oxygen and glucose undergoes slowly-evolving apoptosis through the activation of caspases under the blockade of excitotoxicity (Gwag et al., 1995; Gottron et al., 1997). Accordingly, the combined treatment with a NMDA antagonist and a caspase inhibitor results in synergetic neuroprotection against hypoxic-ischemic injury in vitro and in vivo (Ma et al., 1998; Schulz et al., 1998; Allen et al., 1999; Choi, 2001).

Neurotrophins enhance neuronal survival by preventing programmed cell death, or the apoptosis of developing

Table 1. Comparison of apoptosis, oncosis, and hypoxic-ischemic neuronal death

\begin{tabular}{|c|c|c|c|}
\hline & Apoptosis & Oncosis & Ischemia \\
\hline \multicolumn{4}{|l|}{ Criteria for Oncosis } \\
\hline Cell body swelling & & + & + \\
\hline Scattered condensation of nuclear chromatin & & + & + \\
\hline Dilation of mitochondria & & + & + \\
\hline Early loss of plasma membrane & & + & + \\
\hline Potentiation by trophic factors & & + & + \\
\hline Prevention by antioxidants & & + & + \\
\hline Prevention by glutamate antagonists & & + & + \\
\hline \multicolumn{4}{|l|}{ Criteria for Apoptosis } \\
\hline Membrane blebbing & + & & \\
\hline Cell body shrinkage & + & & \\
\hline Aggregation and condensation of nuclear chromatin & + & & \\
\hline Early loss of nuclear membrane & + & & \\
\hline DNA ladder & + & + & + \\
\hline TUNNEL staining & + & + & + \\
\hline Cytochrome c release & + & + & + \\
\hline Prevention by caspase inhibitors & + & & + \\
\hline Prevention by trophic factors & + & & + \\
\hline Prevention by protein synthesis inhibitors & + & & + \\
\hline Prevention by bcl-2 & + & & + \\
\hline
\end{tabular}


neurons (Davies, 1994; Snider, 1994). The neuroprotective effects of neurotrophins have been demonstrated under various pathological conditions. For example, neurotrophins protect various populations of neurons from axotomy (Hefti, 1986; Yan et al., 1992; Mey and Thanos, 1993; Chiu et al., 1994; Cohen et al., 1994; Mansour-Robaey et al., 1994; Friedman et al., 1995). Neurotrophins can attenuate neuronal death following global or focal cerebral ischemia (Shigeno et al., 1991; Beck et al., 1994; Chan, 1996). Besides their beneficial effects, neurotrophins appear to exacerbate neuronal injury under certain circumstances. BDNF, NT-3, or NT-4/5 renders neurons highly vulnerable to the deprivation of oxygen and glucose, possibly by enhancing the $\mathrm{Ca}^{2+}$ influx through NMDA glutamate receptors, and thereby oncosis (Fernandez-Sanchez and Novelli, 1993; Koh et al., 1995). BDNF or NGF potentiates neuronal cell oncosis by reactive oxygen species or nitric oxide (Gwag et al., 1996; Park et al., 1998; Kim et al., 1999; Ishikawa et al., 2000). The neuroprotective action of neurotrophins therefore appears to be limited to apoptosis, and should be compromised with the potentiation effects of NMDA or free radical neurotoxicity.

Accumulating evidence demonstrates that excitotoxicity, oxidative stress, and apoptosis contribute to hypoxic-ischemic neuronal death through mutually exclusive pathways. To date, glutamate antagonists, anti-oxidants, or anti-apoptosis agents, such as growth factors, have been examined to treat hypoxicischemic brain injury. However, the therapeutic efficacy of neuroprotective drugs against each-excitotoxicity, oxidative stress, or apoptosis-can be confronted with deleterious effects on the other death pathways that also participate in the process of hypoxic-ischemic neuronal death. In the future, an appropriate combination of glutamate antagonists, antioxidants, and anti-apoptosis agents should be applied for maximal neuroprotection against hypoxic-ischemic injury.

\section{Conclusion}

Excitotoxicity, oxidative stress, and apoptosis comprise major routes of hypoxic-ischemic neuronal death. Each route is likely activated and propagated through selective transmembrane and intracellular signaling systems. Further understanding of the distinct and integrated mechanisms that lead to the three death routes is warranted for the efficient and secure treatment of hypoxic-ischemic brain injury.

Acknowledgments This work was supported by a National Research Laboratory Grant from the Korean Ministry of Science and Technology (BJG), and in part by the Korea Science and Engineering Foundation (KOSEF) through the Brain Disease Research Center at Ajou University (BJG).

\section{References}

Alessandrini, A., Namura, S., Moskowitz, M. A. and Bonventre, J. V. (1999) MEK1 protein kinase inhibition protects against damage resulting from focal cerebral ischemia. Proc. Natl. Acad. Sci. USA 96, 12866-12869.

Allen, J. W., Knoblach, S. M. and Faden, A. I. (1999) Combined mechanical trauma and metabolic impairment in vitro induces NMDA receptor-dependent neuronal cell death and caspase-3dependent apoptosis. FASEB J. 13, 1875-1882.

Ankarcrona, M., Dypbukt, J. M., Bonfoco, E., Zhivotovsky, B., Orrenius, S., Lipton, S. A. and Nicotera, P. (1995) Glutamateinduced neuronal death: a succession of necrosis or apoptosis depending on mitochondrial function. Neuron 15, 961-973.

Antonawich, F. J., Federoff, H. J. and Davis, J. N. (1999) BCL-2 transduction, using a herpes simplex virus amplicon, protects hippocampal neurons from transient global ischemia. Exp. Neurol. 156, 130-137.

Arai, K., Nishiyama, N., Matsuki, N. and Ikegaya, Y. (2001) Neuroprotective effects of lipoxygenase inhibitors against ischemic injury in rat hippocampal slice cultures. Brain Res. 904, 167-172.

Atlante, A., Valenti, D., Gagliardi, S. and Passarella, S. (2000) A sensitive method to assay the xanthine oxidase activity in primary cultures of cerebellar granule cells. Brain Res. Protoc. 6, $1-5$.

Au, A. M., Chan, P. H. and Fishman, R. A. (1985) Stimulation of phospholipase A2 activity by oxygen-derived free radicals in isolated brain capillaries. J. Cell. Biochem. 27, 449-53.

Baeuerle, P. A. and Baltimore, D. (1996) NF-kappa B: ten years after. Cell 87, 13-20.

Barone, F. C., Irving, E. A., Ray, A. M., Lee, J. C., Kassis, S., Kumar, S., Badger, A. M., White, R. F., McVey, M. J., Legos, J. J., Erhardt, J. A., Nelson, A. H., Ohlstein, E. H., Hunter, A. J., Ward, K., Smith, B. R., Adams, J. L. and Parsons, A. A. (2001) SB 239063, a Second-Generation p38 MitogenActivated Protein Kinase Inhibitor, Reduces Brain Injury and Neurological Deficits in Cerebral Focal Ischemia. $J$. Pharmacol. Exp. Ther. 296, 312-321.

Beck, T., Lindholm, D., Castren, E. and Wree, A. (1994) Brainderived neurotrophic factor protects against ischemic cell damage in rat hippocampus. J. Cereb. Blood Flow Metab. 14, 689-692.

Beckman, J. S. (1996) Oxidative damage and tyrosine nitration from peroxynitrite. Chem. Res. Toxicol. 9, 836-844.

Benveniste, H., Drejer, J., Schousboe, A. and Diemer, N. H. (1984) Elevation of the extracellular concentrations of glutamate and aspartate in rat hippocampus during transient cerebral ischemia monitored by intracerebral mecrodialysis. $J$. Neurochem. 43, 1369-1374.

Bonventre, J. V. (1997) Roles of phospholipases A2 in brain cell and tissue injury associated with ischemia and excitotoxicity. $J$. Lipid Mediat. Cell Signal. 16, 199-208.

Bonventre, J. V., Huang, Z., Taheri, M. R., O'Leary, E., Li, E., Moskowitz, M. A. and Sapirstein, A. (1997) Reduced fertility and postischaemic brain injury in mice deficient in cytosolic phospholipase $\mathrm{A}_{2}$. Nature 390, 622-625.

Bredesen, D. E. (1994) Neuronal apoptosis: Genetic and biochemical modulation, in Apoptosis II: The Molecular Basis of Apoptosis in desease, Tomei, L. D. and Cope, F. O. (eds.), pp. 397-421, Cold Spring Harbor Laboratory Press, Plainview, New York.

Brookes, P. S., Bolanos, J. P. and Heales, S. J. (1999) The assumption that nitric oxide inhibits mitochondrial ATP 
synthesis is correct. FEBS Lett. 446, 261-263.

Buchan, A., Li, H. and Pulsinelli, W. A. (1991) The N-methyl-Daspartate antagonist, MK-801, fails to protect against neuronal damage caused by transient, severe forebrain ischemia in adult rats. J. Neurosci. 11, 1049-1056.

Buchan, A. M., Xue, D., Huang, Z. G., Smith, K. H. and Lesiuk, H. (1991) Delayed AMPA receptor blockade reduces cerebral infarction induced by focal ischemia. Neuroreport 2, 473-476.

Budd, S. L. and Nicholls, D. G. (1998) Mitochondria in the life and death of neurons. Essays. Biochem. 33, 43-52.

Cao, W., Carney, J. M., Duchon, A., Floyd, R. A. and Chevion, M. (1988) Oxygen free radical involvement in ischemia and reperfusion injury to brain. Neurosci. Lett. 88, 233-238.

Carafoli, E. (1991) Calcium pump of the plasma membrane. Physiol. Rev. 71, 129-153.

Carafoli, E. and Molinari, M. (1998) Calpain: a protease in search of a function? Biochem. Biophys. Res. Commun. 247, 193-203.

Cassina, A. and Radi, R. (1996) Differential inhibitory action of nitric oxide and peroxynitrite on mitochondrial electron transport. Arch. Biochem. Biophys. 328, 309-16.

Chan, P. H. (1996) Role of oxidants in ischemic brain damage. Stroke 27, 1124-1129.

Chao, D. T. and Korsmeyer, S. J. (1998) BCL-2 family: regulators of cell death. Annu. Rev. Immunol. 16, 395-419.

Charriaut-Marlangue, C. and Ben-Ari, Y. (1995) A cautionary note on the use of the TUNEL stain to determine apoptosis. Neuroreport 7, 61-64.

Cheema, Z. F., Wade, S. B., Sata, M., Walsh, K., Sohrabji, F. and Miranda, R. C. (1999) Fas/Apo [apoptosis]-1 and associated proteins in the differentiating cerebral cortex: induction of caspase-dependent cell death and activation of NF-kappaB. $J$. Neurosci. 19, 1754-1770.

Chen, J., Nagayama, T., Jin, K., Stetler, R. A., Zhu, R. L., Graham, S. H. and Simon, R. P. (1998) Induction of caspase-3like protease may mediate delayed neuronal death in the hippocampus after transient cerebral ischemia. J. Neurosci. 18, 4914-4928.

Chiu, A. Y., Chen, E. W. and Loera, S. (1994) Distinct neurotrophic responses of axotomized motor neurons to BDNF and CNTF in adult rats. Neuroreport 5, 693-696.

Choi, D. W. (1987) Ionic dependence of glutamate neurotoxicity. J. Neurosci. 7, 369-379.

Choi, D. W. (2001) Excitotoxicity, apoptosis, and ischemic stroke. J. Biochem. Mol. Biol. 34, 8-14.

Churn, S. B., Limbrick, D., Sombati, S. and DeLorenzo, R. J. (1995) Excitotoxic activation of the NMDA receptor results in inhibition of calcium/calmodulin kinase II activity in cultured hippocampal neurons. J. Neurosci. 15, 3200-3214.

Clapp, L. E., Klette, K. L., DeCoster, M. A., Bernton, E., Petras, J. M., Dave, J. R., Laskosky, M. S., Smallridge, R. C. and Tortella, F. C. (1995) Phospholipase A2-induced neurotoxicity in vitro and in vivo in rats. Brain Res. 693, 101-111.

Cohen, A., Bray, G. M. and Aguayo, A. J. (1994) Neurotrophin-4/ 5 (NT-4/5) increases adult rat retinal ganglion cell survival and neurite outgrowth in vitro. J. Neurobiol. 25, 953-959.

Colbourne, F., Sutherland, G. R. and Auer, R. N. (1999) Electron microscopic evidence against apoptosis as the mechanism of neuronal death in global ischemia. J. Neurosci. 19, 4200-4210.

Cole, T. B., Robbins, C. A., Wenzel, H. J., Schwartzkroin, P. A. and Palmiter, R. D. (2000) Seizures and neuronal damage in mice lacking vesicular zinc. Epilepsy Res. 39, 153-169.

Collaco-Moraes, Y., Aspey, B., Harrison, M. and de Belleroche, J. (1996) Cyclo-oxygenase-2 messenger RNA induction in focal cerebral ischemia. J. Cereb. Blood Flow Metab. 16, 1366-1372.

Colvin, R. A., Davis, N., Nipper, R. W. and Carter, P. A. (2000) Zinc transport in the brain: routes of zinc influx and efflux in neurons. J. Nutr. 130, 1484S-1487S.

Cross, T. G., Scheel-Toellner, D., Henriquez, N. V., Deacon, E., Salmon, M. and Lord, J. M. (2000) Serine/threonine protein kinases and apoptosis. Exp. Cell Res. 256, 34-41.

Dalkara, T., Yoshida, T., Irikura, K. and Moskowitz, M. A. (1994) Dual role of nitric oxide in focal cerebral ischemia. Neuropharmacology 33, 1447-1452.

Darzynkiewicz, Z., Bruno, S., Del Bino, G., Gorczyca, W., Hotz, M. A., Lassota, P. and Traganos, F. (1992) Features of apoptotic cells measured by flow cytometry. Cytometry 13, 795-808.

Davies, A. M. (1994) The role of neurotrophins in the developing nervous system. J. Neurobiol. 25, 1334-1348.

Dawson, T. M., Dawson, V. L. and Snyder, S. H. (1992) A novel neuronal messenger molecule in brain: the free radical, nitric oxide. Ann. Neurol. 32, 297-311.

Dawson, V. L., Dawson, T. M., Bartley, D. A., Uhl, G. R. and Snyder, S. H. (1993) Mechanisms of nitric oxide-mediated neurotoxicity in primary brain cultures. J. Neurosci. 13, 26512661.

Deibel, M. A., Ehmann, W. D. and Markesbery, W. R. (1996) Copper, iron, and zinc imbalances in severely degenerated brain regions in Alzheimer's disease: possible relation to oxidative stress. J. Neurol. Sci. 143, 137-142.

Desagher, S. and Martinou, J. C. (2000) Mitochondria as the central control point of apoptosis. Trends. Cell Biol. 10, 369377.

Ding, D., Moskowitz, S. I., Li, R., Lee, S. B., Esteban, M., Tomaselli, K., Chan, J. and Bergold, P. J. (2000) Acidosis induces necrosis and apoptosis of cultured hippocampal neurons. Exp. Neurol. 162, 1-12.

Dubinsky, J. M. and Levi, Y. (1998) Calcium-induced activation of the mitochondrial permeability transition in hippocampal neurons. J. Neurosci. Res. 53, 728-741.

Dugan, L. L., Sensi, S. L., Canzoniero, L. M., Handran, S. D., Rothman, S. M., Lin, T. S., Goldberg, M. P. and Choi, D. W. (1995) Mitochondrial production of reactive oxygen species in cortical neurons following exposure to N-methyl-D-aspartate. $J$. Neurosci. 15, 6377-6388.

Dumuis, A., Pin, J. P., Oomagari, K., Sebben, M. and Bockaert, J. (1990) Arachidonic acid released from striatal neurons by joint stimulation of ionotropic and metabotropic quisqualate receptors. Nature 347, 182-184.

Dykens, J. A. (1994) Isolated cerebral and cerebellar mitochondria produce free radicals when exposed to elevated $\mathrm{CA}^{2+}$ and $\mathrm{Na}^{+}$: implications for neurodegeneration. J. Neurochem. 63, 584-591.

Earnshaw, W. C., Martins, L. M. and Kaufmann, S. H. (1999) Mammalian caspases: structure, activation, substrates, and functions during apoptosis. Annu. Rev. Biochem. 68, 383-424.

Ellison, G. (1995) The N-methyl-D-aspartate antagonists phencyclidine, ketamine and dizocilpine as both behavioral and anatomical models of the dementias. Brain Res. Rev. 20, 250267.

Enari, M., Sakahira, H., Yokoyama, H., Okawa, K., Iwamatsu, A. 
and Nagata, S. (1998) A caspase-activated DNase that degrades DNA during apoptosis, and its inhibitor ICAD. Nature 391, 4350.

Enright, H., Hebbel, R. P. and Nath, K. A. (1994) Internucleosomal cleavage of DNA as the sole criterion for apoptosis may be artifactual. J. Lab. Clin. Med. 124, 63-68.

Faddis, B. T., Hasbani, M. J. and Goldberg, M. P. (1997) Calpain activation contributes to dendritic remodeling after brief excitotoxic injury in vitro. J. Neurosci. 17, 951-959.

Felderhoff-Mueser, U., Taylor, D. L., Greenwood, K., Kozma, M., Stibenz, D., Joashi, U. C., Edwards, A. D. and Mehmet, H. (2000) Fas/CD95/APO-1 can function as a death receptor for neuronal cells in vitro and in vivo and is upregulated following cerebral hypoxic-ischemic injury to the developing rat brain. Brain Pathol. 10, 17-29.

Fernandez-Schanchez, M. T. and Novelli A. (1993) Basic fibroblast growth factor protects cerebellar neurons in primary culture from NMDA and non-NMDA receptor mediated neurotoxicity. FEBS Lett. 335, 124-131. 1993.

Fix, A. S., Horn, J. W., Wightman, K. A., Johnson, C. A., Long, G. G., Storts, R. W., Farber, N., Wozniak, D. F. and Olney, J. W. (1993) Neuronal vacuolization and necrosis induced by the noncompetitive N-methyl-D-aspartate (NMDA) antagonist MK(+)801 (dizocilpine maleate): a light and electron microscopic evaluation of the rat retrosplenial cortex. Exp. Neurol. 123, 204-215.

Frederickson, C. J. and Moncrieff, D. W. (1994) Zinc-containing neurons. Biol. Signals 3, 127-139.

Freund, W. D. and Reddig, S. (1994) AMPA/Zn $\left({ }^{2+}\right)$-induced neurotoxicity in rat primary cortical cultures: involvement of Ltype calcium channels. Brain Res. 654, 257-264.

Friedman, B., Kleinfeld, D., Ip, N. Y., Verge, V. M., Moulton, R., Boland, P., Zlotchenko, E., Lindsay, R. M. and Liu, L. (1995) BDNF and NT-4/5 exert neurotrophic influences on injured adult spinal motor neurons. J. Neurosci. 15, 1044-1056.

Fujimura, M., Morita-Fujimura, Y., Murakami, K., Kawase, M. and Chan, P. H. (1998) Cytosolic redistribution of cytochrome c after transient focal cerebral ischemia in rats. J. Cereb. Blood Flow Metab. 18, 1239-1247.

Fukunaga, K., Soderling, T. R. and Miyamoto, E. (1992) Activation of $\mathrm{Ca}^{2+} /$ calmodulin-dependent protein kinase II and protein kinase $\mathrm{C}$ by glutamate in cultured rat hippocampal neurons. J. Biol. Chem. 267, 22527-22533.

Furlong, I. J., Ascaso, R., Lopez, R. A. and Collins, M. K. (1997) Intracellular acidification induces apoptosis by stimulating ICElike protease activity. J. Cell Sci. 110, 653-661.

Gavrieli, Y., Sherman, Y. and Ben-Sasson, S. A. (1992) Identification of programmed cell death in situ via specific labeling of nuclear DNA fragmentation. J. Cell Biol. 119, 493501.

Ghatan, S., Larner, S., Kinoshita, Y., Hetman, M., Patel, L., Xia, Z., Youle, R. J. and Morrison, R. S. (2000) p38 MAP kinase mediates bax translocation in nitric oxide-induced apoptosis in neurons. J. Cell Biol. 150, 335-347.

Gill, D. L., Ghosh, T. K. and Mullaney, J. M. (1989) Calcium signaling mechanisms in endoplasmic reticulum activated by inositol 1,4,5-trisphosphate and GTP. Cell Calcium 10, 363374.

Giulivi, C., Boveris, A. and Cadenas, E. (1995) Hydroxyl radical generation during mitochondrial electron transfer and the formation of 8-hydroxydesoxyguanosine in mitochondrial DNA. Arch. Biochem. Biophys. 316, 909-16.

Goldberg, M. P., Weiss, J. H., Pham, P. C. and Choi, D. W. (1987) $\mathrm{N}$-methyl-D-aspartate receptors mediate hypoxic neuronal injury in cortical culture. J. Pharmac. Exp. Ther. 243, 784-791.

Goodman, Y. and Mattson, M. P. (1996) Ceramide protects hippocampal neurons against excitotoxic and oxidative insults, and amyloid beta-peptide toxicity. J. Neurochem. 66, 869-872.

Gorter, J. A., Petrozzino, J. J., Aronica, E. M., Rosenbaum, D. M., Opitz, T., Bennett, M. V., Connor, J. A. and Zukin, R. S. (1997) Global ischemia induces downregulation of Glur2 mRNA and increases AMPA receptor-mediated $\mathrm{Ca}^{2+}$ influx in hippocampal CA1 neurons of gerbil. J. Neurosci. 17, 61796188.

Gottron, F. J., Ying, H. S. and Choi, D. W. (1997) Caspase inhibition selectively reduces the apoptotic component of oxygen-glucose deprivation-induced cortical neuronal cell death. Mol. Cell Neurosci. 9, 159-169.

Grasl-Kraupp, B., Ruttkay-Nedecky, B., Koudelka, H., Bukowska, K., Bursch, W. and Schulte-Hermann, R. (1995) In situ detection of fragmented DNA (TUNEL assay) fails to discriminate among apoptosis, necrosis, and autolytic cell death: a cautionary note. Hepatology 21, 1465-1468.

Greenberg, J. H., Uematsu, D., Araki, N., Hickey, W. F. and Reivich, M. (1990) Cytosolic free calcium during focal cerebral ischemia and the effects of nimodipine on calcium and histologic damage. Stroke 21, IV72-IV77.

Greenlund, L. J., Deckwerth, T. L. and Johnson, E. M. (1995) Superoxide dismutase delays neuronal apoptosis: a role for reactive oxygen species in programmed neuronal death. Neuron 14, 303-315.

Grilli, M., Pizzi, M., Memo, M. and Spano, P. F. (1996) Neuroprotection by aspirin and sodium salicylate through blockade of NF-kB activation. Science 274, 1383-1385.

Gross, A., Jockel, J., Wei, M. C. and Korsmeyer, S. J. (1998) Enforced dimerization of BAX results in its translocation, mitochondrial dysfunction and apoptosis. EMBO J. 17, 38783885.

Gunter, K. K. and Gunter, T. E. (1994) Transport of calcium by mitochondria. J. Bioenerg. Biomembr. 26, 471-485.

Gunter, T. E. and Pfeiffer, D. R. (1990) Mechanisms by which mitochondria transport calcium. Am. J. Physiol. 258, C755C786.

Gwag, B. J., Ryu, B. R., Lee, Y. A., Chang, S-Y., Noh, J-H., Chung, J-M. and Yoon, S-H. (2000) Multiple neuroprotective effects of sulfasalazine against NMDA, free radicals and zinc, presented at 30th annual meeting of society for neuroscience, New Orleans.

Gwag, B. J., Canzoniero, L. M., Sensi, S. L., DeMaro, J. A., Koh, J. Y., Goldberg, M. P., Jacquin, M. and Choi, D. W. (1999) Calcium ionophores can induce either apoptosis or necrosis in cultured cortical neurons. Neuroscience 90, 1339-1348.

Gwag, B. J., Koh, J. Y., Chen, M. M., Dugan, L. L., Behrens, M. M., Lobner, D. and Choi, D. W. (1995) BDNF or IGF-I potentiates free radical-mediated injury in cortical cell cultures. Neuroreport 7, 93-96.

Gwag, B. J., Koh, J. Y., DeMaro, J. A., Ying, H. S., Jacquin, M. and Choi, D. W. (1997) Slowly triggered excitotoxicity occurs by necrosis in cortical cultures. Neuroscience 77, 393-401.

Gwag, B. J., Lobner, D., Koh, J. Y., Wie, M. B. and Choi, D. W. 
(1995) Blockade of glutamate receptors unmasks neuronal apoptosis after oxygen-glucose deprivation in vitro. Neuroscience 68, 615-619.

Haber, F. and Weiss, J. (1934) The catalytic decomposition of hydrogen peroxide by iron salts, Proc. R. Soc., London A 147, 332.

Hajimohammadreza, I., Probert, A. W., Coughenour, L. L., Borosky, S. A., Marcoux, F. W., Boxer, P. A. and Wang, K. K. (1995) A specific inhibitor of calcium/calmodulin-dependent protein kinase-II provides neuroprotection against NMDA- and hypoxia/hypoglycemia-induced cell death. J. Neurosci. 15, 4093-4101.

Hanson, S. K., Grotta, J. C., Waxham, M. N., Aronowski, J. and Ostrow, P. (1994) Calcium/calmodulin-dependent protein kinase II activity in focal ischemia with reperfusion in rats. Stroke 25, 466-473.

Hasegawa, K., Yoshioka, H., Sawada, T. and Nishikawa, H. (1993) Direct measurement of free radicals in the neonatal mouse brain subjected to hypoxia: an electron spin resonance spectroscopic study. Brain. Res. 607, 161-166.

Hefti, F. (1986) Nerve growth factor (NGF) promotes survival of septal cholinergic neurons after fimbrial transections. $J$. Neurosci. 6, 2155-2162.

Herdegen, T., Claret, F. X., Kallunki, T., Martin-Villalba, A., Winter, C., Hunter, T. and Karin, M. (1998) Lasting N-terminal phosphorylation of c-Jun and activation of c-Jun N-terminal kinases after neuronal injury. J. Neurosci. 18, 5124-5135.

Hewett, S. J., Uliasz, T. F., Vidwans, A. S. and Hewett, J. A. (2000) Cyclooxygenase-2 contributes to N-methyl-D-aspartatemediated neuronal cell death in primary cortical cell culture. $J$. Pharmacol. Exp. Ther. 293, 417-425.

Hockenbery, D. M., Oltvai, Z. N., Yin, X. M., Milliman, C. L. and Korsmeyer, S. J. (1993) Bcl-2 functions in an antioxidant pathway to prevent apoptosis. Cell 75, 241-251.

Hollmann, M. and Heinemann, S. (1994) Cloned glutamate receptors. Annu. Rev. Neurosci. 17, 31-108.

Hong, S. C., Goto, Y., Lanzino, G., Soleau, S., Kassell, N. F. and Lee, K. S. (1994) Neuroprotection with a calpain inhibitor in a model of focal cerebral ischemia. Stroke 25, 663-669.

Hsu, Y. T., Wolter, K. G. and Youle, R. J. (1997) Cytosol-tomembrane redistribution of Bax and Bcl-X(L) during apoptosis. Proc. Natl. Acad. Sci. USA 94, 3668-3672.

Hwang, J. Y., Kim, Y. H., Ahn, Y. H., Wie, M. B. and Koh, J. Y. (1999) N-Methyl-D-aspartate receptor blockade induces neuronal apoptosis in cortical culture. Exp. Neurol. 159, 124130.

Iadecola, C., Niwa, K., Nogawa, S., Zhao, X., Nagayama, M., Araki, E., Morham, S. and Ross, M. E. (2001) Reduced susceptibility to ischemic brain injury and N-methyl-Daspartate-mediated neurotoxicity in cyclooxygenase-2-deficient mice. Proc. Natl. Acad. Sci. USA 98, 1294-1299.

Iadecola, C., Zhang, F. and Xu, X. (1995) Inhibition of inducible nitric oxide synthase ameliorates cerebral ischemic damage. Am. J. Physiol. 268, R286-R292.

Iadecola, C., Zhang, F., Xu, S., Casey, R. and Ross, M. E. (1995) Inducible nitric oxide synthase gene expression in brain following cerebral ischemia. J. Cereb. Blood Flow Metab. 15, 378-384.

Ikonomidou, C., Bosch, F., Miksa, M., Bittigau, P., Vockler, J., Dikranian, K., Tenkova, T. I., Stefovska, V., Turski, L. and
Olney, J. W. (1999) Blockade of NMDA receptors and apoptotic neurodegeneration in the developing brain. Science 283, 70-74.

Ip, Y. T. and Davis, R. J. (1998) Signal transduction by the c-Jun $\mathrm{N}$-terminal kinase (JNK)--from inflammation to development. Curr. Opin. Cell Biol. 10, 205-219.

Irving, E. A., Barone, F. C., Reith, A. D., Hadingham, S. J. and Parsons, A. A. (2000) Differential activation of MAPK/ERK and $\mathrm{p} 38 / \mathrm{SAPK}$ in neurons and glia following focal cerebral ischemia in the rat. Mol. Brain Res. 77, 65-75.

Isenmann, S., Stoll, G., Schroeter, M., Krajewski, S., Reed, J. C. and Bahr, M. (1998) Differential regulation of Bax, Bcl-2, and Bcl-X proteins in focal cortical ischemia in the rat. Brain Pathol. 8, 49-62.

Ishikawa, Y., Ikeuchi, T. and Hatanaka, H. (2000) Brain-derived neurotrophic factor accelerates nitric oxide donor-induced apoptosis of cultured cortical neurons. J. Neurochem. 75, 494502.

Jin, K., Graham, S. H., Nagayama, T., Goldsmith, P. C., Greenberg, D. A., Zhou, A. and Simon, R. P. (2001) Altered Expression of the Neuropeptide-Processing Enzyme Carboxypeptidase $\mathrm{E}$ in the Rat Brain After Global Ischemia. $J$. Cereb. Blood Flow Metab. 21, 1422-1429.

Kahn, R. A., Panah, M. and Weinberger, J. (1997) Modulation of ischemic excitatory neurotransmitter and gamma-aminobutyric acid release during global temporary cerebral ischemia by selective neuronal nitric oxide synthase inhibition. Anesth. Analg. 84, 997-1003.

Kawasaki, H., Morooka, T., Shimohama, S., Kimura, J., Hirano, T., Gotoh, Y. and Nishida, E. (1997) Activation and involvement of p38 mitogen-activated protein kinase in glutamate-induced apoptosis in rat cerebellar granule cells. $J$. Biol. Chem. 272, 18518-18521.

Kerr, J. F., Wyllie, A. H. and Currie, A. R. (1972) Apoptosis: a basic biological phenomenon with wide-ranging implications in tissue kinetics. Br. J. Cancer 26, 239-257.

Khaled, A. R., Kim, K., Hofmeister, R., Muegge, K. and Durum, S. K. (1999) Withdrawal of IL-7 induces Bax translocation from cytosol to mitochondria through a rise in intracellular $\mathrm{pH}$. Proc. Natl. Acad. Sci. USA 96, 14476-14481.

Khaled, A. R. and Durum, S. K. (2001) From cytosol to mitochondria: The Bax translocation story. J. Biochem. Mol. Biol. 34, 391-394.

Kharbanda, S., Saxena, S., Yoshida, K., Pandey, P., Kaneki, M., Wang, Q., Cheng, K., Chen, Y. N., Campbell, A., Sudha, T., Yuan, Z. M., Narula, J., Weichselbaum, R., Nalin, C. and Kufe, D. (2000) Translocation of SAPK/JNK to mitochondria and interaction with $\mathrm{Bcl}-\mathrm{x}(\mathrm{L})$ in response to DNA damage. J. Biol. Chem. 275, 322-327.

Khodorov, B., Pinelis, V., Vergun, O., Storozhevykh, T. and Vinskaya, N. (1996) Mitochondrial deenergization underlies neuronal calcium overload following a prolonged glutamate challenge. FEBS Lett. 397, 230-234.

Kim, D. K., Rordorf, G., Nemenoff, R. A., Koroshetz, W. J. and Bonventre, J. V. (1995) Glutamate stably enhances the activity of two cytosolic forms of phospholipase A2 in brain cortical cultures. Biochem. J. 310, 83-90.

Kim, D. Y., Kim, S. H., Choi, H. B., Min, C. and Gwag, B. J. (2001) High abundance of GluR1 mRNA and reduced Q/R editing of GluR2 mRNA in individual NADPH-diaphorase 
neurons. Mol. Cell Neurosci. 17, 1025-1033.

Kim, E. Y., Woo, H. G., Lee, S. H. and Gwag, B. J. (1999) A causative activation of cyclooxygenase for zinc-induced generation of reactive oxygen species in cortical neurons, presented at 29th annual meeting of society for neuroscience, Florida.

Kim, E. Y., Koh, J. Y., Kim, Y. H., Sohn, S., Joe, E. and Gwag, B. J. (1999) $\mathrm{Zn}^{2+}$ entry produces oxidative neuronal necrosis in cortical cell cultures. Eur. J. Neurosci. 11, 327-334.

Kim, Y. H., Kim, E. Y., Gwag, B. J., Sohn, S. and Koh, J. Y. (1999) Zinc-induced cortical neuronal death with features of apoptosis and necrosis: mediation by free radicals. Neuroscience 89, 175-82.

Knowles, R. G. and Moncada, S. (1994) Nitric oxide syntheses in mammals. Biochem. J. 298, 249-258.

Ko, H. W., Han, K. S., Kim, E. Y., Ryu, B. R., Yoon, W. J., Jung, Y. K., Kim, S. U. and Gwag, B. J. (2000) Synergetic activation of p38 mitogen-activated protein kinase and caspase-3-like proteases for execution of calyculin A-induced apoptosis but not $\mathrm{N}$-methyl-d-aspartate-induced necrosis in mouse cortical neurons. J. Neurochem. 74, 2455-2461.

Ko, H. W., Park, K. Y., Kim, H., Han, P. L., Kim, Y. U., Gwag, B. J. and Choi, E. J. (1998) $\mathrm{Ca}^{2+}$-mediated activation of c-Jun $\mathrm{N}$-terminal kinase and nuclear factor kappa B by NMDA in cortical cell cultures. J. Neurochem. 71, 1390-1395.

Koh, J. Y. and Choi, D.W. (1994) Zinc toxicity on cultured cortical neurons: involvement of N-methyl-D-aspartate receptors. Neuroscience 60, 1049-1057.

Koh, J. Y., Goldberg, M. P., Hartley, D. M. and Choi, D. W. (1990) Non-NMDA receptor-mediated neurotoxicity in cortical culture. J. Neurosci. 10, 693-705.

Koh, J. Y., Gwag, B. J., Lobner, D. and Choi, D. W. (1995) Potentiated necrosis of cultured cortical neurons by neurotrophins [see comments]. Science 268, 573-575.

Koh, J. Y., Suh, S. W., Gwag, B. J., He, Y. Y., Hsu, C. Y. and Choi, D. W. (1996) The role of zinc in selective neuronal death after transient global cerebral ischemia. Science 272, 10131016.

Kondo, Y., Ogawa, N., Asanuma, M., Ota, Z. and Mori, A. (1995) Regional differences in late-onset iron deposition, ferritin, transferrin, astrocyte proliferation, and microglial activation after transient forebrain ischemia in rat brain. J. Cereb. Blood. Flow. Metab. 15, 216-26.

Kontos, H. A. (1987) Oxygen radicals from arachidonate metabolism in abnormal vascular responses. Am. Rev. Respir. Dis. 136, 474-477.

Kooy, N. W., Royall, J. A., Ischiropoulos, H. and Beckman, J. S. (1994) Peroxynitrite-mediated oxidation of dihydrorhodamine 123. Free. Radic. Biol. Med. 16, 149-56.

Krajewski, S., Krajewska, M., Ellerby, L. M., Welsh, K., Xie, Z., Deveraux, Q. L., Salvesen, G. S., Bredesen, D. E., Rosenthal, R. E., Fiskum, G. and Reed, J. C. (1999) Release of caspase-9 from mitochondria during neuronal apoptosis and cerebral ischemia. Proc. Natl. Acad. Sci. USA 96, 5752-5757.

Krajewski, S., Mai, J. K., Krajewska, M., Sikorska, M., Mossakowski, M. J. and Reed, J. C. (1995) Upregulation of bax protein levels in neurons following cerebral ischemia. $J$. Neurosci. 15, 6364-6376.

Kramer, R. M. and Sharp, J. D. (1997) Structure, function and regulation of $\mathrm{Ca}^{2+}$-sensitive cytosolic phospholipase A2
(cPLA2). FEBS Lett. 410, 49-53.

Krause, G. S., White, B. C., Aust, S. D., Nayini, N. R. and Kumar, K. (1988) Brain cell death following ischemia and reperfusion: a proposed biochemical sequence. Crit. Care. Med. 16, 714-726.

Kroemer, G., Dallaporta, B. and Resche-Rigon, M. (1998) The mitochondrial death/life regulator in apoptosis and necrosis. Annu. Rev. Physiol. 60, 619-642.

Krohn, A. J., Preis, E. and Prehn, J. H. (1998) Staurosporineinduced apoptosis of cultured rat hippocampal neurons involves caspase-1-like proteases as upstream initiators and increased production of superoxide as a main downstream effector. $J$. Neurosci. 18, 8186-8197.

Kruman, I., Guo, Q. and Mattson, M. P. (1998) Calcium and reactive oxygen species mediate staurosporine-induced mitochondrial dysfunction and apoptosis in PC12 cells. J. Neurosci. Res. 51, 293-308.

Kummer, J. L., Rao, P. K. and Heidenreich, K. A. (1997) Apoptosis induced by withdrawal of trophic factors is mediated by p38 mitogen-activated protein kinase. J. Biol. Chem. 272, 20490-20494.

Lazarewicz, J. W., Wroblewski, J. T. and Costa, E. (1990) Nmethyl-D-aspartate-sensitive glutamate receptors induce calcium- mediated arachidonic acid release in primary cultures of cerebellar granule cells. J. Neurochem. 55, 1875-1881.

Le-Niculescu, H., Bonfoco, E., Kasuya, Y., Claret, F. X., Green, D. R. and Karin, M. (1999) Withdrawal of survival factors results in activation of the JNK pathway in neuronal cells leading to Fas ligand induction and cell death. Mol. Cell Biol. 19, 751-763.

Lee, J. Y., Cole, T. B., Palmiter, R. D. and Koh, J. Y. (2000) Accumulation of zinc in degenerating hippocampal neurons of ZnT3-null mice after seizures: evidence against synaptic vesicle origin. J. Neurosci. 20, RC79.

Lee, J. Y., Kim, Y. H. and Koh, J. Y. (2001) Protection by pyruvate against transient forebrain ischemia in rats. $J$. Neurosci. 21, RC171.

Lee, K. S., Frank, S., Vanderklish, P., Arai, A. and Lynch, G. (1991) Inhibition of proteolysis protects hippocampal neurons from ischemia. Proc. Natl. Acad. Sci. USA 88, 7233-7237.

Li, Y., Chopp, M., Jiang, N., Zhang, Z. G. and Zaloga, C. (1995) Induction of DNA fragmentation after 10 to 120 minutes of focal cerebral ischemia in rats. Stroke 26, 1252-1257.

Li, Y., Sharov, V. G., Jiang, N., Zaloga, C., Sabbah, H. N. and Chopp, M. (1995) Ultrastructural and light microscopic evidence of apoptosis after middle cerebral artery occlusion in the rat. Am. J. Pathol. 146, 1045-1051.

Linnik, M. D., Zobrist, R. H. and Hatfield, M. D. (1993) Evidence supporting a role for programmed cell death in focal cerebral ischemia in rats. Stroke 24, 2002-2008.

Lipton, S. A., Choi, Y. B., Pan, Z. H., Lei, S. Z., Chen, H. S., Sucher, N. J., Loscalzo, J., Singel, D. J. and Stamler, J. S. (1993) A redox-based mechanism for the neuroprotective and neurodestructive effects of nitric oxide and related nitrosocompounds. Nature 364, 626-632.

Liu, Z. Q., Kunimatsu, M., Yang, J. P., Ozaki, Y., Sasaki, M. and Okamoto, T. (1996) Proteolytic processing of nuclear factor kappa B by calpain in vitro. FEBS Lett. 385, 109-113.

Luetjens, C. M., Bui, N. T., Sengpiel, B., Munstermann, G., Poppe, M., Krohn, A. J., Bauerbach, E., Krieglstein, J. and 
Prehn, J. H. (2000) Delayed mitochondrial dysfunction in excitotoxic neuron death: cytochrome $\mathrm{c}$ release and a secondary increase in superoxide production. J. Neurosci. 20, 5715-5723.

Ma, J., Endres, M. and Moskowitz, M. A. (1998) Synergistic effects of caspase inhibitors and MK-801 in brain injury after transient focal cerebral ischemia in mice. Br. J. Pharmacol. 124, 756-762.

MacManus, J. P., Buchan, A. M., Hill, I. E., Rasquinha, I. and Preston, E. (1993) Global ischemia can cause DNA fragmentation indicative of apoptosis in rat brain. Neurosci. Lett. 164, 89-92.

Manev, H., Favaron, M., Siman, R., Guidotti, A. and Costa, E. (1991) Glutamate neurotoxicity is independent of calpain I inhibition in primary cultures of cerebellar granule cells. $J$. Neurochem. 57, 1288-1295.

Mansour-Robaey, S., Clarke, D. B., Wang, Y. C., Bray, G. M. and Aguayo, A. J. (1994) Effects of ocular injury and administration of brain-derived neurotrophic factor on survival and regrowth of axotomized retinal ganglion cells. Proc. Natl. Acad. Sci. USA 91, 1632-1636.

Maroney, A. C., Glicksman, M. A., Basma, A. N., Walton, K. M., Knight, E. J., Murphy, C. A., Bartlett, B. A., Finn, J. P., Angeles, T., Matsuda, Y., Neff, N. T. and Dionne, C. A. (1998) Motoneuron apoptosis is blocked by CEP-1347 (KT 7515), a novel inhibitor of the JNK signaling pathway. J. Neurosci. 18, 104-111.

Martin-Villalba, A., Herr, I., Jeremias, I., Hahne, M., Brandt, R., Vogel, J., Schenkel, J., Herdegen, T. and Debatin, K. M. (1999) CD95 ligand (Fas-L/APO-1L) and tumor necrosis factor-related apoptosis-inducing ligand mediate ischemia-induced apoptosis in neurons. J. Neurosci. 19, 3809-3817.

Martin, D. P., Schmidt, R. E., DiStefano, P. S., Lowry, O. H., Carter, J. G. and Johnson, E. M. (1988) Inhibitors of protein synthesis and RNA synthesis prevent neuronal death caused by nerve growth factor deprivation. J. Cell Biol. 106, 829-844.

Martinou, J. C., Dubois-Dauphin, M., Staple, J. K., Rodriguez, I., Frankowski, H., Missotten, M., Albertini, P., Talabot, D., Catsicas, S. and Pietra, C. (1994) Overexpression of BCL-2 in transgenic mice protects neurons from naturally occurring cell death and experimental ischemia. Neuron 13, 1017-1030.

Matsui, T., Nagafuji, T., Mori, T. and Asano, T. (1997) $\mathrm{N}$ omeganitro-L-arginine attenuates early ischemic neuronal damage of prolonged focal cerebral ischemia and recirculation in rats. Neurol. Res. 19, 192-203.

Matsushita, K., Wu, Y., Qiu, J., Lang-Lazdunski, L., Hirt, L., Waeber, C., Hyman, B. T., Yuan, J. and Moskowitz, M. A. (2000) Fas receptor and neuronal cell death after spinal cord ischemia. J. Neurosci. 20, 6879-6887.

Matsuyama, S., Llopis, J., Deveraux, Q. L., Tsien, R. Y. and Reed, J. C. (2000) Changes in intramitochondrial and cytosolic $\mathrm{pH}$ : early events that modulate caspase activation during apoptosis. Nat. Cell Biol. 2, 318-325.

Matsuyama, T., Hata, R., Yamamoto, Y., Tagaya, M., Akita, H., Uno, H., Wanaka, A., Furuyama, J. and Sugita, M. (1995) Localization of Fas antigen mRNA induced in postischemic murine forebrain by in situ hybridization. Mol. Brain Res. 34, 166-172.

Mattson, M. P., Goodman, Y., Luo, H., Fu, W. and Furukawa, K. (1997) Activation of NF-kappaB protects hippocampal neurons against oxidative stress-induced apoptosis: evidence for induction of manganese superoxide dismutase and suppression of peroxynitrite production and protein tyrosine nitration. $J$. Neurosci. Res. 49, 681-697.

McCord, J. M., Roy, R. S. and Schaffer, S. W. (1985) Free radicals and myocardial ischemia. The role of xanthine oxidase. Adv. Myocardiol. 5, 183-189.

Merrill, J. E., Murphy, S. P., Mitrovic, B., Mackenzie-Graham, A., Dopp, J. C., Ding, M., Griscavage, J., Ignarro, L. J. and Lowenstein, C. J. (1997) Inducible nitric oxide synthase and nitric oxide production by oligodendrocytes. J. Neurosci. Res. 48, 372-384.

Merry, D. E. and Korsmeyer, S. J. (1997) Bcl-2 gene family in the nervous system. Annu. Rev. Neurosci. 20, 245-267.

Mey, J. and Thanos, S. (1993) Intravitreal injections of neurotrophic factors support the survival of axotomized retinal ganglion cells in adult rats in vivo. Brain Res. 602, 304-317.

Middleton, G., Hamanoue, M., Enokido, Y., Wyatt, S., Pennica, D., Jaffray, E., Hay, R. T. and Davies, A. M. (2000) Cytokineinduced nuclear factor kappa B activation promotes the survival of developing neurons. J. Cell Biol. 148, 325-332.

Mielke, K. and Herdegen, T. (2000) JNK and p38 stress kinases-degenerative effectors of signal-transduction-cascades in the nervous system. Prog. Neurobiol. 61, 45-60.

Miettinen, S., Fusco, F. R., Yrjanheikki, J., Keinanen, R., Hirvonen, T., Roivainen, R., Narhi, M., Hokfelt, T. and Koistinaho, J. (1997) Spreading depression and focal brain ischemia induce cyclooxygenase- 2 in cortical neurons through $\mathrm{N}$-methyl-D-aspartic acid-receptors and phospholipase A2. Proc. Natl. Acad. Sci. USA, 94, 6500-6505.

Morioka, M., Fukunaga, K., Nagahiro, S., Kurino, M., Ushio, Y. and Miyamoto, E. (1995) Glutamate-induced loss of $\mathrm{Ca}^{2+}$ calmodulin-dependent protein kinase II activity in cultured rat hippocampal neurons. J. Neurochem. 64, 2132-2139.

Murphy, S., Simmons, M. L., Agullo, L., Garcia, A., Feinstein, D. L., Galea, E., Reis, D. J., Minc-Golomb, D. and Schwartz, J. P. (1993) Synthesis of nitric oxide in CNS glial cells. Trends. Neurosci. 16, 323-328.

Nagata, S. (1997) Apoptosis by death factor. Cell 88, 355-365.

Namura, S., Iihara, K., Takami, S., Nagata, I., Kikuchi, H., Matsushita, K., Moskowitz, M. A., Bonventre, J. V. and Alessandrini, A. (2001) Intravenous administration of MEK inhibitor U0126 affords brain protection against forebrain ischemia and focal cerebral ischemia. Proc. Natl. Acad. Sci. USA 98, 11569-11574.

Namura, S., Zhu, J., Fink, K., Endres, M., Srinivasan, A., Tomaselli, K. J., Yuan, J. and Moskowitz, M. A. (1998) Activation and cleavage of caspase-3 in apoptosis induced by experimental cerebral ischemia. J. Neurosci. 18, 3659-3668.

Nanri, K., Montecot, C., Springhetti, V., Seylaz, J. and Pinard, E. (1998) The selective inhibitor of neuronal nitric oxide synthase, 7-nitroindazole, reduces the delayed neuronal damage due to forebrain ischemia in rats. Stroke 29, 1248-1253.

Neumar, R. W., Hagle, S. M., DeGracia, D. J., Krause, G. S. and White, B. C. (1996) Brain mu-calpain autolysis during global cerebral ischemia. J. Neurochem. 66, 421-424.

Nicholls, D. and Attwell, D. (1990) The release and uptake of excitatory amino acids. Trends. Pharmacol. Sci. 11, 462-468.

Nicoletti, I., Migliorati, G., Pagliacci, M. C., Grignani, F. and Riccardi, C. (1991) A rapid and simple method for measuring thymocyte apoptosis by propidium iodide staining and flow 
cytometry. J. Immunol. Methods 139, 271-279.

Noh, J. S., Kang, H. J., Kim, E.Y., Sohn, S., Chung, Y. K., Kim, S. U. and Gwag, B. J. (2000) Haloperidol-induced neuronal apoptosis: role of p38 and c-Jun-NH(2)-terminal protein kinase. J. Neurochem. 75, 2327-2334.

Noh, K. M. and Koh, J. Y. (2000) Induction and activation by zinc of NADPH oxidase in cultured cortical neurons and astrocytes. J. Neurosci. 20, RC111.

O'Neill, M. J., Hicks, C. and Ward, M. (1996) Neuroprotective effects of 7-nitroindazole in the gerbil model of global cerebral ischemia. Eur. J. Pharmacol. 310, 115-122.

Olney, J. W., Labruyere, J., Wang, G., Wozniak, D. F., Price, M. T. and Sesma, M. A. (1991) NMDA antagonist neurotoxicity: mechanism and prevention. Science 254, 1515-1518.

Ostwald, K., Hagberg, H., Andine, P. and Karlsson, J. O. (1993) Upregulation of calpain activity in neonatal rat brain after hypoxic-ischemia. Brain Res. 630, 289-294.

Ouagazzal, A., Nieoullon, A. and Amalric, M. (1993) Effects of dopamine D1 and D2 receptor blockade on MK-801-induced hyperlocomotion in rats. Psychopharmacology (Berl.) 111, 427434.

Ozawa, H., Shioda, S., Dohi, K., Matsumoto, H., Mizushima, H., Zhou, C. J., Funahashi, H., Nakai, Y., Nakajo, S. and Matsumoto, K. (1999) Delayed neuronal cell death in the rat hippocampus is mediated by the mitogen-activated protein kinase signal transduction pathway. Neurosci. Lett. 262, 57-60.

Park, E. C., Jou, I. and Gwag, B. J. (1998) Nerve growth factor potentiates the oxidative necrosis of striatal cholinergic neurons. NeuroReport 9, 687-690.

Pellegrini-Giampietro, D. E., Gorter, J. A., Bennett, M. V. and Zukin, R. S. (1997) The GluR2 (GluR-B) hypothesis: $\mathrm{Ca}^{2+}{ }^{2+}$ permeable AMPA receptors in neurological disorders. Trends. Neurosci. 20, 464-470.

Pellegrini-Giampietro, D. E., Zukin, R. S., Bennett, M. V., Cho, S. and Pulsinelli, W. A. (1992) Switch in glutamate receptor subunit gene expression in CA1 subfield of hippocampus following global ischemia in rats. Proc. Natl. Acad. Sci. USA 89, 10499-10503.

Peng, T. I., Jou, M. J., Sheu, S. S. and Greenamyre, J. T. (1998) Visualization of NMDA receptor-induced mitochondrial calcium accumulation in striatal neurons. Exp. Neurol. 149, 112.

Piantadosi, C. A. and Zhang, J. (1996) Mitochondrial generation of reactive oxygen species after brain ischemia in the rat. Stroke 27, 327-332.

Planas, A. M., Soriano, M. A., Rodriguez-Farre, E. and Ferrer, I. (1995) Induction of cyclooxygenase-2 mRNA and protein following transient focal ischemia in the rat brain. Neurosci. Lett. 200, 187-190.

Plesnila, N., Zinkel, S., Le, D. A., Amin-Hanjani, S., Wu, Y., Qiu, J., Chiarugi, A., Thomas, S. S., Kohane, D. S., Korsmeyer, S. J. and Moskowitz, M. A. (2001) BID mediates neuronal cell death after oxygen/ glucose deprivation and focal cerebral ischemia. Proc. Natl. Acad. Sci. USA (in press).

Portera-Cailliau, C., Hedreen, J. C., Price, D. L., and Koliatsos, V. E. (1995) Evidence for apoptotic cell death in Huntington disease and excitotoxic animal models. J. Neurosci. 15, 37753787.

Prehn, J. H., Jordan, J., Ghadge, G. D., Preis, E., Galindo, M. F., Roos, R. P., Krieglstein, J. and Miller, R. J. (1997) $\mathrm{Ca}^{2+}$ and reactive oxygen species in staurosporine-induced neuronal apoptosis. J. Neurochem. 68, 1679-1685.

Radi, R., Beckman, J. S., Bush, K. M. and Freeman, B. A. (1991) Peroxynitrite oxidation of sulfhydryls. The cytotoxic potential of superoxide and nitric oxide. J. Biol. Chem. 266, 4244-4250.

Radi, R., Beckman, J. S., Bush, K. M. and Freeman, B. A. (1991) Peroxynitrite-induced membrane lipid peroxidation: the cytotoxic potential of superoxide and nitric oxide. Arch. Biochem. Biophys. 288, 481-487.

Radi, R., Rodriguez, M., Castro, L. and Telleri, R. (1994) Inhibition of mitochondrial electron transport by peroxynitrite. Arch. Biochem. Biophys. 308, 89-95.

Radi, R., Sims, S., Cassina, A. and Turrens, J. F. (1993) Roles of catalase and cytochrome $\mathrm{c}$ in hydroperoxide-dependent lipid peroxidation and chemiluminescence in rat heart and kidney mitochondria. Free. Radic. Biol. Med. 15, 653-9.

Rami, A. and Krieglstein, J. (1993) Protective effects of calpain inhibitors against neuronal damage caused by cytotoxic hypoxia in vitro and ischemia in vivo. Brain Res. 609, 67-70.

Raoul, C., Henderson, C. E. and Pettmann, B. (1999) Programmed cell death of embryonic motoneurons triggered through the Fas death receptor. J. Cell Biol. 147, 1049-1062.

Ratan, R. R., Murphy, T. H. and Baraban, J. M. (1994) Oxidative stress induces apoptosis in embryonic cortical neurons. $J$. Neurochem. 62, 376-379.

Rego, A. C., Santos, M. S. and Oliveira, C. R. (2000) Glutamatemediated inhibition of oxidative phosphorylation in cultured retinal cells. Neurochem. Int. 36, 159-166.

Reynolds, J. E., Li, J., Craig, R. W. and Eastman, A. (1996) BCL2 and MCL-1 expression in Chinese hamster ovary cells inhibits intracellular acidification and apoptosis induced by staurosporine. Exp. Cell Res. 225, 430-436.

Roberts-Lewis, J. M., Savage, M. J., Marcy, V. R., Pinsker, L. R. and Siman, R. (1994) Immunolocalization of calpain Imediated spectrin degradation to vulnerable neurons in the ischemic gerbil brain. J. Neurosci. 14, 3934-3944.

Robertson, J. D., Orrenius, S. and Zhivotovsky, B. (2000) Review: nuclear events in apoptosis. J. Struct. Biol. 129, 346-358.

Rogawski, M. A. (2000) Low affinity channel blocking (uncompetitive) NMDA receptor antagonists as therapeutic agents--toward an understanding of their favorable tolerability. Amino. Acids 19, 133-149.

Rordorf, G., Uemura, Y. and Bonventre, J. V. (1991) Characterization of phospholipase A2 (PLA2) activity in gerbil brain: enhanced activities of cytosolic, mitochondrial, and microsomal forms after ischemia and reperfusion. J. Neurosci. 11, 1829-1836.

Rosenbaum, D. M., D'Amore, J., Llena, J., Rybak, S., Balkany, A. and Kessler, J. A. (1998) Pretreatment with intraventricular aurintricarboxylic acid decreases infarct size by inhibiting apoptosis following transient global ischemia in gerbils. Ann. Neurol. 43, 654-660.

Ross, D. T. and Duhaime, A. C. (1989) Degeneration of neurons in the thalamic reticular nucleus following transient ischemia due to raised intracranial pressure: excitotoxic degeneration mediated via non-NMDA receptors. Brain Res. 501, 129-143.

Rothman, S. M., Yamada, K. A. and Lancaster, N. (1993) Nordihydroguaiaretic acid attenuates NMDA neurotoxicity-action beyond the receptor. Neuropharmacology 32, 1279-1288.

Ryu, B., Kim, E. Y. and Gwag B. J. (1998) Oxidative stress is not 
required for neuronal apoptosis in cortical cell cultures, presented at 28th Annual Meeting of Society for Neuroscience, LA.

Sairanen, T., Ristimaki, A., Karjalainen-Lindsberg, M. L., Paetau, A., Kaste, M. and Lindsberg, P. J. (1998) Cyclooxygenase-2 is induced globally in infracted human brain. Ann. Neurol. 43, 738-747.

Saluja, I., Song, D., O'Regan, M. H. and Phillis, J. W. (1997) Role of phospholipase A2 in the release of free fatty acids during ischemia-reperfusion in the rat cerebral cortex. Neurosci. Lett. 233, 97-100.

Samdani, A. F., Dawson, T. M. and Dawson, V. L. (1997) Nitric oxide synthase in models of focal ischemia. Stroke 28, 12831288.

Sanfeliu, C., Hunt, A. and Patel, A. J. (1990) Exposure to Nmethyl-D-aspartate increases release of arachidonic acid in primary cultures of rat hippocampal neurons and not in astrocytes. Brain Res. 526, 241-248.

Sapirstein, A. and Bonventre, J. V. (2000) Phospholipases A2 in ischemic and toxic brain injury. Neurochem. Res. 25, 745-753.

Schulz, J. B., Weller, M., Matthews, R. T., Heneka, M. T., Groscurth, P., Martinou, J. C., Lommatzsch, J., von Coelln, R., Wullner, U., Loschmann, P. A., Beal, M. F., Dichgans, J. and Klockgether, T. (1998) Extended therapeutic window for caspase inhibition and synergy with MK-801 in the treatment of cerebral histotoxic hypoxia. Cell Death. Differ. 5, 847-857.

Schwarzschild, M. A., Cole, R. L., Meyers, M. A. and Hyman, S. E. (1999) Contrasting calcium dependencies of SAPK and ERK activations by glutamate in cultured striatal neurons. $J$. Neurochem. 72, 2248-2255.

Schweizer, M. and Richter, C. (1994) Gliotoxin stimulates $\mathrm{Ca}^{2+}$ release from intact rat liver mitochondria. Biochemistry 33, 13401-13405.

Sensi, S. L., Canzoniero, L. M., Yu, S. P., Ying, H. S., Koh, J. Y., Kerchner, G. A. and Choi, D. W. (1997) Measurement of intracellular free zinc in living cortical neurons: routes of entry. J. Neurosci. 17, 9554-9564.

Sensi, S. L., Yin, H. Z., Carriedo, S. G., Rao, S. S. and Weiss, J. H. (1999) Preferential $\mathrm{Zn}^{2+}$ influx through $\mathrm{Ca}^{2+}$-permeable AMPA/kainate channels triggers prolonged mitochondrial superoxide production. Proc. Natl. Acad. Sci. USA 96, 24142419.

Seo, S. Y., Kim, E. Y., Kim, H. and Gwag, B. J. (1999) Neuroprotective effect of high glucose against NMDA, free radical, and oxygen-glucose deprivation through enhanced mitochondrial potentials. J. Neurosci. 19, 8849-8855.

Seubert, P., Larson, J., Oliver, M., Jung, M. W., Baudry, M. and Lynch, G. (1988) Stimulation of NMDA receptors induces proteolysis of spectrin in hippocampus. Brain Res. 460, 189194.

Sevanian, A., Muakkassah-Kelly, S. F. and Montestruque, S. (1983) The influence of phospholipase A2 and glutathione peroxidase on the elimination of membrane lipid peroxides. Arch. Biochem. Biophys. 223, 441-52.

Shackelford, D. A., Yeh, R. Y., Hsu, M., Buzsaki, G. and Zivin, J. A. (1995) Effect of cerebral ischemia on calcium/calmodulindependent protein kinase II activity and phosphorylation. $J$. Cereb. Blood Flow Metab. 15, 450-461.

Shapira, S., Kadar, T. and Weissman, B. A. (1994) Dosedependent effect of nitric oxide synthase inhibition following transient forebrain ischemia in gerbils. Brain Res. 668, 80-84.

Sheardown, M. J., Nielsen, E. O., Hansen, A. J., Jacobsen, P. and Honore, T. (1990) 2,3-Dihydroxy-6-nitro-7-sulfamoylbenzo(f)quinozaline: A neuroprotectant for cerebral ischemia. Science 247, 571-574.

Sheline, C. T., Behrens, M. M. and Choi, D. W. (2000) Zincinduced cortical neuronal death: contribution of energy failure attributable to loss of $\mathrm{NAD}(+)$ and inhibition of glycolysis. $J$. Neurosci. 20, 3139-3146.

Shigeno, T., Mima, T., Takakura, K., Graham, D. I., Kato, G., Hashimoto, Y. and Furukawa S. (1991) Amelioration of delayed neuronal death in hippocampus by nerve growth factor. J. Neurosci. 11, 2914-2919.

Shim, J. S., Lee, H. J., Park, S. S., Cha, B. G. and Chang, H. R. (2001) Curcumin-induced apoptosis of A-431 cells involves caspase-3 activation. J. Biochem. Mol. Biol. 34, 189-193.

Siesjo, B. K., Katsura, K. I., Kristian, T., Li, P. A. and Siesjo, P. (1996) Molecular mechanisms of acidosis-mediated damage. Acta Neurochir. Suppl. (Wien.) 66, 8-14.

Simon, R. P., Swan, J. H., Griffiths, T. and Meldrum, B. S. (1984) Blockade of N-methyl-D-aspartate receptors may protect against ischemic damage in the brain. Science 226, 850-852.

Snider, B. J., Gottron, F. J. and Choi, D. W. (1999) Apoptosis and necrosis in cerebrovascular disease. Ann. N.Y. Acad. Sci. 893, 243-253.

Snider, W. D. (1994) Functions of the neurotrophins during nervous system development: What the knockouts are teaching us. Cell 77, 627-638.

Sohn, S., Kim, E. Y. and Gwag, B. J. (1998) Glutamate neurotoxicity in mouse cortical neurons: a typical necrosis with DNA ladders and chromatin condensation. Neurosci. Lett. 240, $1-4$.

Sorimachi, H., Ishiura, S. and Suzuki, K. (1997) Structure and physiological function of calpains. Biochem. J. 328, 721-732.

Srivastava, R. K., Sollott, S. J., Khan, L., Hansford, R., Lakatta, E. G. and Longo, D. L. (1999) Bcl-2 and Bcl-X(L) block thapsigargin-induced nitric oxide generation, c-Jun $\mathrm{NH}(2)-$ terminal kinase activity, and apoptosis. Mol. Cell Biol. 19, 5659-5674.

Stagliano, N. E., Dietrich, W. D., Prado, R., Green, E. J. and Busto, R. (1997) The role of nitric oxide in the pathophysiology of thromboembolic stroke in the rat. Brain Res. 759, 32-40.

Stout, A. K., Raphael, H. M., Kanterewicz, B. I., Klann, E. and Reynolds, I. J. (1998) Glutamate-induced neuron death requires mitochondrial calcium uptake. Nat. Neurosci. 1, 366-373.

Strasser, A., O'Connor, L. and Dixit, V. M. (2000) Apoptosis signaling. Annu. Rev. Biochem. 69, 217-245.

Sucher, N. J., Awobuluyi, M., Choi, Y. B. and Lipton, S. A. (1996) NMDA receptors: from genes to channels. Trends. Pharmacol. Sci. 17, 348-355.

Sugawara, T., Fujimura, M., Morita-Fujimura, Y., Kawase, M. and Chan, P. H. (1999) Mitochondrial release of cytochrome c corresponds to the selective vulnerability of hippocampal CA1 neurons in rats after transient global cerebral ischemia. $J$. Neurosci. 19, RC39.

Sugino, T., Nozaki, K., Takagi, Y., Hattori, I., Hashimoto, N., Moriguchi, T. and Nishida, E. (2000) Activation of mitogenactivated protein kinases after transient forebrain ischemia in gerbil hippocampus. J. Neurosci. 20, 4506-4514. 
Suh, S. W., Chen, J. W., Motamedi, M., Bell, B., Listiak, K., Pons, N. F., Danscher, G. and Frederickson, C. J. (2000) Evidence that synoptically-released zinc contributes to neuronal injury after traumatic brain injury. Brain Res. 852, 268-273.

Taglialatela, G., Robinson, R. and Perez-Polo, J. R. (1997) Inhibition of nuclear factor kappa B (NFkappaB) activity induces nerve growth factor-resistant apoptosis in PC12 cells. $J$. Neurosci. Res. 47, 155-162.

Takadera, T., Matsuda, I. and Ohyashiki, T. (1999) Apoptotic cell death and caspase-3 activation induced by N-methyl-Daspartate receptor antagonists and their prevention by insulinlike growth factor I. J. Neurochem. 73, 548-556.

Takagi, K., Ginsberg, M. D., Globus, M. Y., Dietrich, W. D., Martinez, E., Kraydieh, S. and Busto, R. (1993) Changes in amino acid neurotransmitters and cerebral blood flow in the ischemic penumbral region following middle cerebral artery occlusion in the rat: correlation with histopathology. J. Cereb. Blood Flow Metab. 13, 575-585.

Takehara, Y., Kanno, T., Yoshioka, T., Inoue, M. and Utsumi, K. (1995) Oxygen-dependent regulation of mitochondrial energy metabolism by nitric oxide. Arch. Biochem. Biophys. 323, 2732.

Tournier, C., Hess, P., Yang, D. D., Xu, J., Turner, T. K., Nimnual, A., Bar-Sagi, D., Jones, S. N., Flavell, R. A. and Davis, R. J. (2000) Requirement of JNK for stress-induced activation of the cytochrome c-mediated death pathway. Science 288, 870-874.

Troy, C. M. and Shelanski, M. L. (1994) Down-regulation of copper/zinc superoxide dismutase causes apoptotic death in PC12 neuronal cells. Proc. Natl. Acad. Sci. USA 91, 63846387.

van Lookeren, C., Thibodeaux, H., van Bruggen, N., Cairns, B., Gerlai, R., Palmer, J. T., Williams, S. P. and Lowe, D. G. (1999) Evidence for a protective role of metallothionein-1 in focal cerebral ischemia. Proc. Natl. Acad. Sci. USA 96, 1287012875.

Vanhoutte, P., Barnier, J. V., Guibert, B., Pages, C., Besson, M. J., Hipskind, R. A. and Caboche, J. (1999) Glutamate induces phosphorylation of Elk-1 and CREB, along with c-fos activation, via an extracellular signal-regulated kinase-dependent pathway in brain slices. Mol. Cell Biol. 19, 136-146.

Velier, J. J., Ellison, J. A., Kikly, K. K., Spera, P. A., Barone, F. C. and Feuerstein, G. Z. (1999) Caspase-8 and caspase-3 are expressed by different populations of cortical neurons undergoing delayed cell death after focal stroke in the rat. $J$. Neurosci. 19, 5932-5941.

Wang, G. J., Randall, R. D. and Thayer, S. A. (1994) Glutamateinduced intracellular acidification of cultured hippocampal neurons demonstrates altered energy metabolism resulting from $\mathrm{Ca}^{2+}$ loads. J. Neurophysiol. 72, 2563-2569.

Wang, H. G., Pathan, N., Ethell, I. M., Krajewski, S., Yamaguchi, Y., Shibasaki, F., McKeon, F., Bobo, T., Franke, T. F. and Reed, J. C. (1999) $\mathrm{Ca}^{2+}$-induced apoptosis through calcineurin dephosphorylation of BAD. Science 284, 339-343.

Wang, K. K. (2000) Calpain and caspase: can you tell the difference? Trends. Neurosci. 23, 20-26.

Wang, K. K., Roufogalis, B. D. and Villalobo, A. (1990) Calpain I activates $\mathrm{Ca}^{2+}$ transport by the human erythrocyte plasma membrane calcium pump. Adv. Exp. Med. Biol. 269, 175-180.

Ward, M. W., Rego, A. C., Frenguelli, B. G. and Nicholls, D. G. (2000) Mitochondrial membrane potential and glutamate excitotoxicity in cultured cerebellar granule cells. J. Neurosci. 20, 7208-7219.

Waxham, M. N., Grotta, J. C., Silva, A. J., Strong, R. and Aronowski, J. (1996) Ischemia-induced neuronal damage: a role for calcium/calmodulin-dependent protein kinase II. $J$. Cereb. Blood Flow Metab. 16, 1-6.

Weiss, J. H., Turetsky, D., Wilke, G. and Choi, D. W. (1994) AMPA/kainate receptor-mediated damage to NADPHdiaphorase- containing neurons is $\mathrm{Ca}^{2+}$ dependent. Neurosci. Lett. 167, 93-96.

Welch, K. M. A., Caplan, L. R., Reis, D. J., Siesjo, S. K. and Weir, B. (1997) Primer on cerebrovascular diseases. San Diego, Academic Press.

White, B. C., Krause, G. S., Aust, S. D. and Eyster, G. E. (1985) Postischemic tissue injury by iron-mediated free radical lipid peroxidation. Ann. Emerg. Med. 14, 804-809.

White, R. J. and Reynolds, I. J. (1996) Mitochondrial depolarization in glutamate-stimulated neurons: an early signal specific to excitotoxin exposure. J. Neurosci. 16, 5688-5697.

White, R. J. and Reynolds, I. J. (1997) Mitochondria accumulate $\mathrm{Ca}^{2+}$ following intense glutamate stimulation of cultured rat forebrain neurons. J. Physiol. 498, 31-47.

Whittemore, E. R., Loo, D. T., Watt, J. A. and Cotman, C. W. (1995) A detailed analysis of hydrogen peroxide-induced cell death in primary neuronal culture. Neuroscience 67, 921-932.

Won, S. J., Ahn, Y. M. and Gwag, B. J. (2000) Activation of FADD and caspase- 8 in ischemic cortical neurons following focal cerebral ischemia in rats, presented at 30th Annual Meeting of the Society for Neuroscience, New Orleans.

Won, S. J., Ko, H. W., Kim, E. Y., Park, E. C., Huh, K., Jung, N. P., Choi, I., Oh, Y. K., Shin, H. C. and Gwag, B. J. (1999) Nuclear factor kappa B-mediated kainate neurotoxicity in the rat and hamster hippocampus. Neuroscience 94, 83-91.

Woo, M., Hakem, R., Soengas, M. S., Duncan, G. S., Shahinian, A., Kagi, D., Hakem, A., McCurrach, M., Khoo, W., Kaufman, S. A., Senaldi, G., Howard, T., Lowe, S. W. and Mak, T. W. (1998) Essential contribution of caspase 3/CPP32 to apoptosis and its associated nuclear changes. Genes Dev. 12, 806-819.

Wyllie, A. H. (1980) Glucocorticoid-induced thymocyte apoptosis is associated with endogenous endonuclease activation. Nature 284, 555-556.

Wyllie, A. H., Morris, R. G., Smith, A. L. and Dunlop, D. (1984) Chromatin cleavage in apoptosis: association with condensed chromatin morphology and dependence on macromolecular synthesis. J. Pathol. 142, 67-77.

Xia, Z., Dickens, M., Raingeaud, J., Davis, R. J. and Greenberg, M. E. (1995) Opposing effects of ERK and JNK-p38 MAP kinases on apoptosis. Science 270, 1326-1331.

Xia, Z., Dudek, H., Miranti, C. K. and Greenberg, M. E. (1996) Calcium influx via the NMDA receptor induces immediate early gene transcription by a MAP kinase/ERK-dependent mechanism. J. Neurosci. 16, 5425-5436.

Yan, Q., Elliott, J. and Snider, W. D. (1992) Brain-derived neurotrophic factor rescues spinal motor neurons from axotomy-induced cell death. Nature 360, 753-755.

Yermilov, V., Yoshie, Y., Rubio, J. and Ohshima, H. (1996) Effects of carbon dioxide/bicarbonate on induction of DNA singlestrand breaks and formation of 8-nitroguanine, 8-oxoguanine and base-propenal mediated by peroxynitrite. FEBS Lett. 399, 67-70. 
Yoshida, T., Limmroth, V., Irikura, K. and Moskowitz, M. A. (1994) The NOS inhibitor, 7-nitroindazole, decreases focal infarct volume but not the response to topical acetylcholine in pial vessels. J. Cereb. Blood Flow Metab. 14, 924-929.

Youdim, M. B., Ben-Shachar, D. and Riederer, P. (1993) The possible role of iron in the etiopathology of Parkinson's Disease. Mov. Disord. 8, 1-12.

Yu, S. P., Yeh, C., Strasser, U., Tian, M. and Choi, D. W. (1999) NMDA receptor-mediated $\mathrm{K}^{+}$efflux and neuronal apoptosis. Science 284, 336-339.
Zaleska, M. M. and Floyd, R. A. (1985) Regional lipid peroxidation in rat brain in vitro: possible role of endogenous iron. Neurochem. Res. 10, 397-410.

Zhang, J., Dawson, V. L., Dawson, T. M. and Snyder, S. H. (1994) Nitric oxide activation of poly(ADP-ribose) synthetase in neurotoxicity. Science 263, 687-689.

Zhang, Y., Marcillat, O., Giulivi, C., Ernster, L. and Davies, K. J. (1990) The oxidative inactivation of mitochondrial electron transport chain components and ATPase. J. Biol. Chem. 265, 16330-16336. 